\title{
Timing of mowing influences genetic diversity and reproductive success in endangered semi- natural grassland plants
}

\section{AUTHOR(S):}

Nakahama, Naoyuki; Uchida, Kei; Ushimaru, Atushi; Isagi, Yuji

\section{CITATION:}

Nakahama, Naoyuki ...[et al]. Timing of mowing influences genetic diversity and reproductive success in endangered semi-natural grassland plants. Agriculture, Ecosystems \& Environment 2016, 221: 20-27

\section{ISSUE DATE:}

2016-04

URL:

http://hdl.handle.net/2433/204553

\section{RIGHT:}

(c) 2016. This manuscript version is made available under the CC-BY-NC-ND 4.0 license

http://creativecommons.org/licenses/by-nc-nd/4.0/; The full-text file will be made open to the public on 1 April 2018 in accordance with publisher's 'Terms and Conditions for Self-Archiving'; この論文は出版社版でありません。引用の際に は出版社版をご確認ご利用ください。; This is not the published version. Please cite only the published version. 
Timing of mowing influences genetic diversity and reproductive success in endangered semi-natural grassland plants

6

7 Naoyuki Nakahamaa,*, Kei Uchida ${ }^{\mathrm{b}}$, Atushi Ushimaruc, ${ }^{\mathrm{c}}$ Yuji Isagi ${ }^{\mathrm{a}}$

8

${ }^{a}$ Graduate School of Agriculture, Kyoto University, Oiwake-cho, Kitashirakawa, Sakyo-ku,

10 Kyoto 606-8502, Japan

$11{ }^{\mathrm{b}}$ Graduate School of Arts and Sciences, The University of Tokyo, 3-8-1 Komaba,

12 Meguro-ku, Tokyo 153-8902, Japan

$13{ }^{\mathrm{c}}$ Graduate School of Human Development and Enviroment, Kobe University, 3-11

14 Tsurukabuto, Nada-ku Kobe, Hyogo 657-8501, Japan

15

* Corresponding author. Tel./Fax: +81 757536129

17

E-mail address: naoyuki.halobates@gmail.com

Running head: Timing of mowing influences grassland plants 


\section{ABSTRACT}

Recent global land-use changes have led to reductions in many herbaceous plant species in semi-natural grassland landscapes. Changes in management frequency and intensity are known to cause declines in plant populations. However, little is known about the impact of changes in the timing of management practices on the genetic diversity as well as the reproductive success of rare semi-natural grassland species. We determined the suitable management (mowing) timing for Vincetoxicum pycnostelma Kitag. (Apocynaceae; Asclepiadoideae), an endangered summer- and autumn-blooming semi-natural grassland herb. We examined $15 \mathrm{~V}$. pycnostelma populations to assess the effects of mowing timing on the genetic diversity of each population using nine microsatellite markers and on pollination and reproductive success. Pollination success was not affected by flowering timing. Mowing during the mid- to late flowering and fruiting periods of $V$. pycnostelma (July-September) had a significant negative effect on the number of inflorescences and total fruits produced, whereas mowing before flowering and growing periods (April-May and November-March) had positive effects on the number of inflorescences and fruits, respectively. Furthermore, mowing during the mid- to late flowering and fruiting periods also caused a significant decrease in genetic diversity. Our results demonstrated that mowing events during the mid- to late flowering and fruiting periods caused significant declines in the genetic diversity and/or reproductive success of $V$. pycnostelma. By contrast, mowing before flowering periods significantly enhanced reproductive success. To conserve semi-natural grassland herb diversity, mowing should be avoided during seasons when the flowering and fruiting periods of many endangered species overlap.

Keywords: Anthropogenic disturbance regime; Conservation; Microsatellite; Rare grassland 
49 plants; Suitable management; Vincetoxicum pycnostelma

50

51

52

53

54

55

56

57

58

59

60

61

62

63

64

65

66

67

68

69

70

71

72 


\section{Introduction}

In recent decades, the area and biodiversity of semi-natural grasslands within agricultural landscapes have been globally and rapidly decreasing because of drastic changes in traditional and extensive land-use systems, garnering much attention from basic and applied ecologists (IUCN, 2012; Kleijn et al., 2011; Krebs et al., 1999; McNeely et al., 1995; Tilman et al., 2001; Tscharntke et al., 2005). Together with recent changes in anthropogenic disturbance (e.g., mowing, burning, and grazing) regimes, abandonments of threatened semi-natural habitats, which have been caused by degradation and conversion of rural life styles and cultures, have decreased plant diversity, particularly the number of rare endangered species in European and Asian semi-natural grasslands (Albrecht and Haider, 2013; Babai and Molnár, 2014; Kleijn et al., 2011; Uchida and Ushimaru, 2014; Uematsu and Ushimaru, 2013).

Although several studies have elucidated the negative impacts of both increases and decreases in disturbance frequency and/or intensity on semi-natural grassland plant diversity (Ekroos et al., 2010; Kleijn et al., 2011; Pöyry et al., 2006; Uchida and Ushimaru, 2014; Uematsu et al., 2010), little is known about the effects of changes in the timing of management practices on plant diversity and the reproductive success of individual plant species (Brys et al., 2004; Endels et al., 2007). Because plant species usually exhibit seasonal reproductive activity (i.e., flowering and fruiting), anthropogenic disturbances during flowering and fruiting periods tend to diminish reproductive success (Brys et al., 2004; Endels et al., 2007; Jantunen et al., 2007). If semi-natural grassland plants have adapted their reproductive periods to traditional management timing, changes in these timings may also negatively impact plant fitness via a reduction in seed production.

The above hypothesis has been tested by several researchers (Brys et al., 2004; Endels et 
al., 2007; Jantunen et al., 2007); however, the process by which changes in management timings cause declines in populations has not been sufficiently examined for plants living within agricultural landscapes. Anthropogenic disturbances during the reproductive period of animal-pollinated flowers may diminish seed production in several ways. The first is a basic reduction in the number of reproductive units. Mowing during flowering and fruiting periods inevitably reduces the numbers of flowers and fruits (Brys et al., 2004; Endels et al., 2007; Jantunen et al., 2007), leading to reduction in seed sets. Second, a reduction flower number results in decreased pollination success. Because both individual- and population-level numbers play important roles in pollinator attraction (Ebeling et al., 2008; Potts et al., 2006), a reduction in flower number can result in lower seed production in both respects.

Furthermore, pollinator abundance and richness could be decreased by changes in disturbance regimes, independent of flower reduction (Hudewenz et al., 2012; Kearns et al., 1998;

Söderström et al., 2001). Thus, to determine the effects of changes in disturbance regime on reproductive success in animal-pollinated plants, these scenarios should be examined simultaneously.

Natural and anthropogenic disturbance regimes can also affect genetic diversity in plant populations (Marchi et al., 2013; Rüdinger et al., 2008). Genetic diversity within a given population is considered important for the conservation of endangered plant species, as genetic diversity is usually positively correlated with fitness: low genetic diversity within a population greatly diminishes fitness through inbreeding depression and qualitative pollen limitation, particularly in self-incompatible species (Johansson et al., 2007; Leimu et al., 2006; Young and Pickup, 2010). Reduced seed recruitment due to mowing and grazing during the annual reproductive period may lower genetic diversity in small and isolated populations. Thus, changes in management practices can cause local extinction of species through a loss 
121 of genetic diversity. However, the effects of the timing of management practices on genetic

122 diversity in semi-natural grassland plants have rarely been investigated and remain unclear.

123 In the present study, we examined the reproductive success and genetic diversity of 15

124 Vincetoxicum pycnostelma Kitag. (Apocynaceae; Asclepiadoideae) populations subjected to

125 different management practices maintained for at least last 10 years. Using this endangered

126 perennial herb species as the study subject, we aimed to elucidate the impact of the timing of

127 an anthropogenic disturbance (mowing) on the sexual reproduction and genetic diversity of a

128 semi-natural grassland plant. Although this species was very common in the region a few

129 decades ago, it has experienced rapid population declines due to changes in land-use in

130 semi-natural grasslands throughout Japan (Environment Agency of Japan, 2000; Uematsu et

131 al., 2010). Vincetoxicum pycnostelma is a representative example of many native herbaceous

132 plants that reproduce from summer to autumn but that have rapidly declined in semi-natural

133 grasslands (Koyanagi and Furukawa, 2013). Assessing the effects of mowing timing is also

134 essential for planning the conservation of endangered semi-natural grassland herbs as well as

135 entire plant communities. We predict that intensive mowing during their flowering and

136 fruiting periods will significantly reduce not only reproductive success but also the genetic

137 diversity of this endangered grassland species. Based on our results, we discuss the

138 importance of traditional management practices and suitable management timings for the

139 conservation of semi-natural grasslands and the diversity of endangered plants, including $V$.

140 pycnostelma.

142 2. Materials and methods

143 2.1. Study species

144 Vincetoxicum pycnostelma is a perennial herb species endemic to the semi-natural grasslands 
146 produce pollinia, which have a sticky appendage called a corpusculum. The flowers are self-incompatible and open at night, and small- and intermediate-sized moths (Lepidoptera) and crane flies are recorded as pollinators (Nakahama et al., 2013a, b; Yamashiro et al., 2008).

149 Relatively large follicle fruits (7 mm in diameter, 5-7 cm in length, including several tens of seeds) mature during September to October. The life-form of the species is geophyte, based on Raunkiaer (1934): rhizomes have many shoot meristems so that above-ground shoots can quickly regrow even after mowing. During recent decades, this species has experienced rapid population declines due to natural succession after land abandonment and development of grasslands. Therefore, it was categorised as Near Threatened (NT) on the Japanese Red List (Ministry of the Environment, Government of Japan, 2012). Moreover, this species is also at risk of regional extinction, as it is listed in 45 of 47 prefectural Red Lists in Japan (Koyanagi and Furukawa, 2013).

\subsection{Study site}

Vincetoxicum pycnostelma populations were investigated at 15 study sites in the Kinki and

Tokai districts in Japan (Fig. A1, Table A1). Semi-natural grasslands have been maintained by anthropogenic activities such as mowing and burning at the study sites. The 15 populations were isolated from other populations by the developed lands, forests and mountains. The geographical distances among the study sites ranged from 5 to $222.9 \mathrm{~km}$. The grassland area of each site was measured using Google Earth (http://earth.google.com/). The total grassland area varied among the sites from 67.7 to $1486.7 \mathrm{~m}^{2}$ (Table 1). To measure population size, we walked around and carefully searched for $V$. pycnostelma plants and counted the number of ramets within each study site, as the species exhibits a phalanx-type clonal growth, and 
ramets were almost identical to genets. The timing and frequency of mowing at each study site were elucidated by interviewing land managers (Table 1). The frequency and timing of mowing management had remained unchanged for at least the most recent decade at each study site, except for sites i and o (Table 1). Mowing (including burning) events in each study year were categorised into five groups based on their timing: during November and March (pre-growing period), during April and May (onset of the growing period), June (early flowering period), July (peak flowering), and during August and September (late flowering and fruiting period) (Table 1). Selective mowing practices (the land manager mowed approximately half the area of each semi-natural grassland) during June and September were also observed, which are commonly observed in traditionally managed grasslands (K. Uchida and A. Ushimaru, personal observation).

\subsection{Sampling of pollination and reproductive success}

To examine male and female pollination success, we examined pollinia removal and deposition on the stigmas of selected flowers. The pollinia of $V$. pycnostelma attach to the proboscis or leg of pollinators and are removed from flowers. Pollinia on the pollinators are then inserted into the stigmatic chamber of other conspecific flowers (Nakahama et al., 2013a; Wyatt and Broyles, 1994). In each population, we arbitrarily selected 10 ramets that had flowers 1-2 months after the most recent mowing, and all flowers in a single inflorescence were collected from each ramet in 2013. If fewer than 10 flowering ramets were available, flower samples were collected from all flowering ramets. In four populations (sites a, d, e, and k), samples could not be collected because flowering ramets were not found; thus, flower samples were obtained for the remaining 11 populations. In the two selective-mowing populations (site $\mathrm{f}$ and $\mathrm{h}$ ), flowers growing in unmown area were also 
193

194

195

196

197

198

199

200

201

202

203

204

205

206

207

208

209

210

211

212

213

214

215

216

collected before mowing. We examined all collected flowers under a stereomicroscope to count both the number of flowers in which at least one pollinium had been removed and the number of pollinated flowers for each inflorescence.

The numbers of inflorescences and total fruits were used as indicators of flowering and fruiting success for each ramet. We examined these metrics in all populations except that of site $\mathrm{n}$, where wild deer foraged the aboveground parts of many $V$. pycnostelma individuals in 2013. In each population, we arbitrarily selected 20-25 ramets (5-15 ramets at the sites with small population sizes) that had regrown after mowing from the whole habitat area and counted the total number of inflorescences and fruits in September or October, when $V$. pycnostelma produces mature fruits (Table A2). Because V. pycnostelma retains inflorescence stalks even after anthesis, we were able to count the number of inflorescences even if flowers no longer remained. Inflorescence and fruit numbers were counted in 2012 (nine populations) and 2013 (14 populations). In addition, we recorded stem diameters at ground level in 2013 as indicators of vegetative growth.

\subsection{Sampling for microsatellite analysis}

In 2012 and 2013, we collected leaf samples from 432 V. pycnostelma individuals in 14 different populations (Table 2). Site j was not examined in the microsatellite analysis due to it very small population. Sample size (12-58 individuals) varied among populations depending on the population size (Table 2).

Genomic DNA was extracted using a modified CTAB method (Milligan, 1992). Seven of the nine loci developed by Nakahama et al. (2012) were used in this study: i.e. Vpy002, Vpy006, Vpy012, Vpy013, Vpy016, Vpy018 and Vpy022. These loci were suitable for the present study because they did not exhibit significant deviation from Hardy-Weinberg 
equilibrium (HWE) (except Vpy022 in one population) and significant linkage equilibrium

218 for any pairs of loci (except Vpy022/Vpy016 in one population) (Nakahama et al., 2012). Two

219 of the nine loci could not be used because they were not amplified from some samples. We designed two additional microsatellite primer pairs (Table A3) using the same protocol as

Nakahama et al. (2012). None of the nine loci pairs exhibited deviation from HWE or significant linkage equilibrium. The genotyping protocol is described in Appendix A1.

\subsection{Statistical analysis of genetic diversity}

The genetic diversity of each population was evaluated in terms of Nei's unbiased expected heterozygosity $\left(H_{\mathrm{E}}\right.$; Nei, 1987), observed heterozygosity $\left(H_{\mathrm{O}}\right)$, the average number of alleles per locus $(A)$, allelic richness $\left(A_{R}\right.$; El Mousadik and Petit, 1996) and the inbreeding coefficient $\left(F_{\mathrm{IS}}\right) . H_{\mathrm{E}}$ and $A_{\mathrm{R}}$ were corrected for differences in sample size for each population.

However, because of a large among-population variation in sample size, we used data from

22 randomly selected individuals for the populations with more than 22 samples in microsatellite analyses (Appendix A2; Tables 2, A4). All parameters were calculated using FSTAT ver. 2.9.3 software (Goudet, 2001). Nei’s genetic distance ( $D_{\mathrm{A}}$; Nei et al., 1983) was calculated using MSA analyzer ver.4.05 (Dieringer and Schlötterer, 2003). Deviation from HWE was also examined using FSTAT.

A Mantel test (Mantel 1967) was used to assess correlations between $D_{\mathrm{A}}$ and the logarithmically transformed geographic distance, performing 9999 permutations in GenAlEx ver. 6.41 (Peakall and Smouse, 2006). We evaluated genetic relationships among populations using Bayesian clustering in STRUCTURE ver. 2.3.4. (Prichard et al., 2009), which assigns individuals into $K$ clusters. Population structure was simulated with values of $K=1-14$ under an admixture model, i.e., the correlated allele frequency model (Hubisz et al., 2009). All runs 
involved 1,000,000 Markov chain Monte Carlo generations after a burn-in period of $1,000,000$ iterations. Ten runs were performed for each value of $K$. The number of clusters was determined by comparing mean values and variability of log likelihoods in each run. To select the optimal value of $K$, STRUCTURE Harvester was used. The $F$ value, amount of genetic drift between each cluster and a common ancestral population, and expected heterozygosity were calculated.

\subsection{Statistical analysis of pollination success, reproductive success and genetic diversity}

Generalised linear mixed models (GLMMs) with binomial errors and a logistic-link function were used to examine the impact of flowering timing on pollination success. In the full model, grassland area $\left(\mathrm{m}^{2}\right)$, population size, sampling date (the number of days after 1 June), and its square were selected as explanatory variables, and population identity was chosen as a random term. The response variables were the percentage of pollinia-removed flowers and pollinated flowers of all flowers for each observed inflorescence in 2013.

In parallel, to examine the impact of mowing timing on flowering and fruiting success, we used GLMMs (Poisson errors and a log-link function). Population and survey year identities were used as random terms. In the full model, the explanatory variables were area, population size and presence/absence (1/0) data of current mowing (including burning) events: November-March, April-May, June, July and August-September. The selective mowing of a given period was treated as 0.5 . We also examined the effects of environmental factors (mean temperature and total precipitation during April and October in 2012 or 2013) as covariates. The response variable was the number of inflorescences in 2013 or fruit number in 2012 and 2013. In addition, we examined linear mixed models (LMMs) to examine the effects of population size and mowing timing on ramet size (stem diameter) as 
265

266

267

268

269

270

271

272

273

274

275

well.

Finally, we examined the effects of mowing timing on genetic diversity with LMMs, in which population and locus identities were included as the random terms. In the full model, explanatory variables were grassland area, population size, mowing timing during the last 10 years and environmental factors (mean temperature and total precipitation from April to October during 1981-2010). In this analysis, the mowing categories at sites i and o were those conducted during years prior to 2010 or 2011 and were different from their current mowing categories because their mowing timings were changed in 2010 or 2011, respectively (Table 1). The response variable was mean $A_{R}$ or arcsin-transformed $H_{\mathrm{E}}$.

For all the analyses, we conducted model selection based on Akaike’s Information Criterion (AIC) to clarify factors strongly influencing response variables. The model with the lowest AIC was regarded as the best model approximating the data for each analysis. All statistical procedures were performed using R software (ver. 2.15.1; R Development Core Team, 2012) and the package lme4.

\section{Results}

\subsection{Pollination, reproductive success and vegetative growth}

The numbers of pollinia-removed and pollinated flowers did not vary with sampling date and population size, whereas they increased with the grassland area in the best model (Fig. 1; Table 3).

Mowing events during July-September had significant negative effects on the numbers of inflorescences and fruits (Fig. 2a, Tables 3, A5). In the best model for inflorescence number, mowing events during April-May and total precipitation had significant positive effects, whereas mowing during July-September had a significantly negative effect on the number of 
289

290

291

292

293

294

295

296

297

298

299

300

301

302

303

304

305

306

307

308

309

310

311

312

inflorescences in 2013 (Table 3). Based on the best model for fruit set, mowing events during November-March had a significant positive effect, whereas mowing during July-September, the area and mean temperature had significant negative effects (Table 3).

Similarly, stem diameter at ground level was also significantly negatively affected by mowing events during June-September, whereas the variable was positively affected by mowing events during November-May (Tables A6, A7). In 2013, stem diameter at ground level was also significantly correlated with the number of inflorescences $(P<0.001)$, indicating that smaller ramets formed fewer inflorescences.

\subsection{Genetic diversity}

$A_{R}$ and $H_{\mathrm{E}}$ for the populations with mowing events during July-September tended to be lower than those of other populations, which were mown during the pre-growing to early flowering period (November-June) or mown selectively (Fig. 2b). In the best models for both $A_{R}$ and $H_{\mathrm{E}}$, mowing events during July-September and population size had significant negative effects (Tables 3, A8).

Genetic distance $\left(D_{\mathrm{A}}\right)$ and geographic distance were not significantly correlated among the 14 populations ( $P=0.057, R^{2}=0.093$; Fig. A2). STRUCTURE analysis indicated that $V$. pycnostelma populations did not exhibit clear spatial genetic clusters between populations (Fig. A3). The variance in log likelihood among runs was high, at $K>7$ (Fig. A3a). The $\Delta K$ value was clearly highest, at $K=6$ (Fig. A3b). Thus, results obtained with $K=6$ are shown (Fig. A3c). Sites a, d, i and o were assigned to clusters 1, 2, 3 and 4, respectively, for which the $F=0.080,0.117,0.246$ and 0.073 and $H_{\mathrm{E}}=0.749,0.721,0.633$ and 0.747 , respectively. The remaining populations were not assigned to specific clusters. 


\section{4. Discussion}

314 We found that mowing during the peak-to-late flowering and fruiting periods (i.e., during July through September) diminished genetic diversity as well as reproductive success in $V$. pycnostelma, which was consistent with our predictions. Furthermore, four populations mown during July-September had unique genetic structures. In contrast, mowing events during the pre-growing (pre-March) or pre-flowering (April-May) periods enhanced reproductive success in $V$. pycnostelma. These results suggest that the timing of mowing greatly influences not only reproductive success but also genetic diversity in endangered semi-natural grassland plant populations. In contrast, the timing of mowing did not affect pollination success in $V$. pycnostelma, suggesting that the cause of low reproductive success and consequent reduction in genetic diversity could be a simple reduction in flowers and fruits due to mowing.

\subsection{Effects of mowing timing on reproductive success}

Mowing events during July-September had a severe negative impact on inflorescence, fruit production and stem diameter at ground level (Tables 3, A6 and A7). These results indicate that mowing during peak flowering and fruiting periods of the species reduced shoot size and produced fewer inflorescences. Although mowing timings have been unchanged during the last decade in most sites, a quick adaptation of growing and reproductive phenology due to the recent mowing timing is not considered to occur. This is because $V$. pycnostelma is perennial so that the same individuals can reproduce for several years. Furthermore, the species requires a few years to start reproduction after seed germination, likely leading to the moderate or long regeneration time in this species. Previous reports have suggested that mowing during flowering and fruiting periods negatively affects the flower and seed 
production of other flowering species (Brys et al., 2004; Endels et al., 2007). Taken together, our current and the previous findings suggest that low reproductive success following mowing during the reproductive period is caused primarily by a simple reduction in the numbers of flowers and fruits and not by a reduction in pollination success.

In contrast, mowing during April-May and November-March enhanced inflorescence and fruit production, respectively. The removal of the above-ground parts of other plant species before the peak growing season might promote growth and underground resource storage of $V$. pycnostelma in spring. The positive effects of mowing before flowering on reproductive success in summer- and autumn-blooming species should be examined in other species and/or in different semi-natural grassland ecosystems.

Pollination success was not affected significantly by flowering timing but instead by the grassland area of each site in $V$. pycnostelma. The flowers of this species are pollinated by very common small- and intermediate-sized moths, the adults of which usually have an active period of more than 3 months (Inoue et al., 1982; Nakahama et al., 2013a, b; Yamashiro et al., 2008). Therefore, a delay in the flowering period due to mowing should not lead to a phenological mismatch between flowering and pollinator activity. Furthermore, $V$. pycnostelma would likely selectively abort fruits, as fruit sets in naturally and hand-pollinated flowers were usually very low (Nakahama et al., 2013b). Consequently, even if pollination success can vary depending on the number of flowers, a variation in fruit set would be diminished by selective abortion.

\subsection{Effects of mowing timing on genetic diversity}

Our results demonstrated that mowing events during peak flowering and fruiting periods had significant negative effects on genetic diversity (Table 3). The reduction of flower number 
and, consequently, of fruit and seed production in every year caused by mowing during this period could decrease genetic diversity in three ways. First, disturbance events at peak flowering would diminish the number of potential mates, likely causing a loss in the genetic diversity of seeds within a given population. Second, the reduction in subsequent fruit production would result in lower genetic diversity in seeds. Because the pollen of Asclepiadoideae plants exists as a pollinium (Endress, 1994), the diversity of paternally inherited genes per individual fruit should be low, corresponding to a single father. Consequently, a reduced number of fruit per population would lead to low genetic diversity in seeds. The study populations are isolated from one another, and therefore gene flow between populations might be limited. Thus, low genetic diversity in seedlings in the next year would gradually diminish the genetic diversity of the population, as gene flow is limited by a reliance on intrapopulation reproduction. Third, reduced fruit production would also result in low genetic diversity in seed banks. Many grassland herbs produce seed banks, which act to restore their populations after anthropogenic disturbances (Willems and Biks, 1998).

Vincetoxicum pycnostelma would also form a long-term soil seed bank because its seeds form large embryos and exhibit physiological dormancy (Martin, 1946; Zhou et al., 2003). Seed banks contribute to the maintenance of genetic diversity at post-disturbance stages of population growth (Honnay et al., 2008; Zaghloul et al., 2013). Therefore, less genetic diversity in seed banks would reduce the genetic diversity of frequently disturbed plant populations.

The genetic diversity of populations that were mown before the flowering peak (July) when plants produced more fruits, tended to be greater compared with the other populations (Fig. 2b). Increased seed production would provide higher levels of genetic diversity in seedlings and/or seed banks. Therefore, to maintain the genetic diversity of $V$. pycnostelma, it 
385

386

387

388

389

390

391

392

393

394

395

396

397

398

399

400

401

402

403

404

405

406

407

408

is clearly important to avoid mowing during the peak flowering and fruiting periods. In particular, the reproductive success of self-incompatible species is often positively correlated with genetic diversity (Leimu et al., 2006; Young and Pickup, 2010). Thus, in self-incompatible V. pycnostelma, a reduction in genetic diversity could subsequently result in a further reduction in reproductive success, likely leading to a negative feedback loop between reproductive success and genetic diversity. In this study, we could not determine why population size had a negative effect on genetic diversity. Mean temperature and total precipitation from April to October had no significant effects, although environmental factors such as temperature, precipitation and soil moisture potentially influence genetic diversity (Avolio and Smith, 2013; Huang et al., 2015).

In the present study, neither clear spatial genetic structure nor significant isolation by distance existed among the populations of $V$. pycnostelma in the Kinki and Tokai districts in Japan, although some populations had unique genetic structures (Fig. A2, A3c). The extent of genetic differentiation of common grassland species such as Miscanthus sinensis and Artemisia indica, which dominate in semi-natural grasslands and whose habitats are the same as $V$. pycnostelma, is low due to the rapid expansion of their distribution range and frequent historical gene flow between populations (Shimono et al., 2013a, b). Because V. pycnostelma was also common in semi-natural grasslands in the past, it may have also rapidly expanded its distribution, as it shares the same grassland habitat and co-exists with the aforementioned grassland species. This rapid expansion may explain the observed low genetic differentiation and unclear spatial genetic structure in V. pycnostelma. At sites a, d, i and o, where mowing during the peak flowering or fruiting periods have been conducted, loss of allele diversity might be the cause of a unique genetic structure (Fig. 2b, A3c). 


\subsection{Decline mechanisms of semi-natural grassland plants}

We demonstrated that mowing events before the flowering period are favourable for the reproductive success of endangered $V$. pycnostelma, whereas those during the peak flowering and fruiting periods would cause significant reductions of not only reproductive success but also genetic diversity. We also found reduced flowering and/or fruiting of other summer- and autumn-blooming endangered species at our study sites where mowing events occurred during their flowering periods (Tables A9, A10). In Japan, traditional mowing with a sickle had been considerably time-consuming and labour-intensive. Therefore, intensive mowing from mid-summer to early autumn had been uncommon to avoid physical overexertion (Baba et al., 1991). Furthermore, selective mowing, which kept unmown grassland areas, had been commonly observed because living plant biomass for livestock fodder and organic fertiliser was constantly necessary throughout the seasons (Arita and Kimura, 1993; Baba et al., 1991; Itoh and Baba, 1999). Consequently, traditional mowing practices had been generally extensive in summer, maintaining many summer- and autumn-blooming rare plants in Japanese semi-natural grasslands (Itoh and Baba, 1999). During recent decades, however, mowing from mid-summer to early autumn has become common practice because of the popularisation of motorised shoulder-type grass-cutting machines, which are compact and mobile. Using the machines, farmers can mow easily and intensively, avoiding physical overxertion even in mid-summer (Arita and Kimura, 1993; Itoh and Baba, 1993). Thus, these changes in mowing timing and frequency may be one factor causing the decline in semi-natural grassland herbs, including V. pycnostelma.

\section{Conclusion}

To the best of our knowledge, this study is the first to demonstrate that the timing of mowing 
433

434

435

436

437

438

439

440

441

442

443

444

445

446

447

448

449

450

451

452

453

454

455

456

affects the genetic diversity of endangered semi-natural grassland herb populations, although the frequency of management practices (mowing and/or burning) has been well documented as being crucial for the conservation of endangered semi-natural grassland herbs (Kleijin et al., 2011; Uchida and Ushimaru, 2014; Zechmeister et al., 2003).

Of the 186 species defined as Japanese grassland herb species by Koyanagi and Furukawa (2013), flowering phenology has been described for 168 (Kitamura et al., 1957; Kitamura et al., 1964; Kitamura and Murata, 1961), 69 of which are currently listed as endangered (described in the Red Lists of over four prefectures). Approximately $70 \%$ of the total species and $75 \%$ of the endangered species have a flowering peak from summer to autumn like $V$. pycnostelma. Thus, the timing of mowing that enhanced the reproductive success and genetic diversity of $V$. pycnostelma would be effective to conserve other endangered grassland herbs. In contrast, mowing during mid-summer to early autumn (July-September) should be avoided. Based on our findings, we suggest that future studies will investigate different species in different semi-natural grasslands throughout the world to confirm the importance of timing management for the conservation of grassland plant species.

\section{ACKNOWLEDGEMENTS}

We thank Y. Hashimoto, E. Imazumi, M. Kagohashi, T. Matsumoto, T. Murase, K. Nagase, K. Ohtoshi, K. Sakai, Y. Sawada, T. Yamaguchi, S. Yoshida, and A. Yoshino, who acted as guides within the V. pycnostelma habitats. We also thank A. Takayanagi, M. Yamasaki, and M. Yokogawa for valuable discussions about and helpful support with this manuscript. This work was supported by a 2012 Grants-in-Aid from the Kansai Organization for Nature Conservation. 
457

458

459

460

461

462

463

464

465

466

467

468

469

470

471

472

473

474

475

\section{References}

Albrecht, H., Haider, S., 2013. Species diversity and life history traits in calcareous grasslands vary along an urbanization gradient. Biol. Conserv. 22, 2243-2267.

Arita, H., Kimura, K., 1993. On the influences of paddy field shape to levee weeding labor-Developing farm land consolidation technique in regarding to labor efficiency of levee weeding (1)-. Trans. Agri. Eng. Soc. 163, 87-94. (in Japanese with English summary).

Avolio, M. L., Smith, M. D., 2013. Correlations between genetic and species diversity: effects of resource quantity and heterogeneity. J. Veg. Sci. 24, 1185-1194.

Baba, T., Itoh, S., Tanaka, M., 1991. A study on the actual conditions of wild grass preservation and use environments in mountainous paddy fields -The case of Hiji area of Hase village- . J. Fac. Sci. Shinshu University, 28, 117-139. (in Japanese).

Babai, D., Molnár, Z., 2014. Small-scale traditional management of highly species-rich grasslands in the Carpathians. Agric. Ecosyst. Environ. 182, 123-130.

Brys, R., Jacquemyn, H., Endels, P., Blust, G.D., Hermy, M., 2004. The effects of grassland management on plant performance and demography in the perennial herb Primula veris. J. Appl. Ecol. 41, 1080-1091.

Dieringer, D., Schlötterer, C., 2003. Microsatellite analyser (MSA): a platform independent analysis tool for large microsatellite data sets. Mol. Ecol. Notes 3, 167-169.

Ebeling, A., Klein, A. M., Schumacher, J., Weisser, W. W., Tscharntke, T., 2008. How does plant richness affect pollinator richness and temporal stability of flower visits? Oikos 117, 1808-1815.

Ekroos, J., Heliölä, J., Kuussaari, M., 2010. Homogenization of lepidopteran communities in intensively cultivated agricultural landscapes. J. Appl. Ecol. 47, 459-467. 
481

482

483

484

485

486

487

488

489

490

491

492

493

494

495

496

497

498

499

500

501

502

503

504

El Mousadik, E.A., Petit, R.J., 1996. High level of genetic differentiation for allelic richness among populations of the argan tree (Argania spinosa [L. ] Skeels) endemic to Morocco. Theor. Appl. Genet. 92, 832-839.

Endels, P., Jacquemyn, H., Brys, R., Hermy, M., 2007. Reinstatement of traditional mowing regimes counteracts population senescence in the rare perennial Primula vulgaris. Appl. Veg. Sci. 10, 351-360.

Endress, P.K., 1994. Diversity and evolutionary biology of tropical flowers. Cambridge University Press, Cambridge.

Environment Agency of Japan, 2000. Threatened Wildlife of Japan - Red Data Book 2nd ed. Vascular Plants. Japan Wildlife Research Center, Tokyo. (in Japanese).

Goudet, J., 2001. FSTAT; A program to estimate and test gene diversities and fixation indices version 2.9.3. http://www2.unil.ch/popgen/softwares/fstat.htm (accessed 01.10.11).

Honnay, O., Bossuyt, B., Jacquemyn, H., Shimono, A., Uchiyama, K., 2008. Can a seed bank maintain the genetic variation in the above ground plant population? Oikos 117, 1-5.

Huang, C.L., Chen, J. H., Tsang, M. H., Chung, J. D., Chang, C. T., Hwang, S. Y., 2015. Influences of environmental and spatial factors on genetic and epigenetic variations in Rhododendron oldhamii (Ericaceae). Tree Gene. Genomes 11, 1-16.

Hubisz, M.J., Falush, D., Stephens, M., Pritchard, J.K., 2009. Inferring weak population structure with the assistance of sample group information. Mol. Ecol. Resour. 9, 1322-1332.

Hudewenz, A., Klein, A.M., Scherber, C., Stanke, L., Tscharntke, T., Vogel, A., Weigelt, A., Weisser, W.W., Ebeling, A., 2012. Herbivore and pollinator responses to grassland management intensity along experimental changes in plant species richness. Biol. Conserv. 150, 42-52. 
505

506

507

508

509

510

511

512

Inoue, H., Sugi, S., Kuroko, H., Moriuchi, S., Kawabe, A., 1982. Moths of Japan 1. and 2. Kodansha, Tokyo. (in Japanese).

IUCN, 2012. The IUCN Red List of Threatened Species. http://www.iucnredlist.org/ (accessed 01.03.14).

Itoh, S., Baba, T., 1993. A study of plant change in mountain paddy embankment management - the case of Hiji area Hase village II- . J. Fac. Sci. Shinshu University, 30, 89-113. (in Japanese).

Itoh, S., Baba, T., 1999. The Man'youshu Anthology and the Wild Flowers of the Paddy Field Embankments. Curtis's Bot. Mag. 16, 139-147.

Jantunen, J., Saarinen, K., Valtonen, A., Saarnio, S., 2007. Flowering and seed production success along roads with different mowing regimes. Appl. Veg. Sci. 10, 285-292.

Johansson, M., Primmer, C.R., Merilä, J., 2007. Does habitat fragmentation reduce fitness and adaptability? A case study of the common frog (Rana temporaria). Mol. Ecol. 16, 2693-2700.

Kearns, C. A., Inouye, D.W., Waser. N.M., 1998. Endangered mutualisms: the conservation of plant-pollinator interactions. Annu. Rev. Ecol. Evol. Syst. 29, 83-112.

Kitamura, S., Murata, G., Hori, M., 1957. Colored Illustrations of Herbaceous Plants of Japan Vol.1. Hoikusha. Osaka. (in Japanese).

Kitamura, S., Murata, G., 1961. Colored Illustrations of Herbaceous Plants of Japan Vol.2. Hoikusha. Osaka. (in Japanese).

Kitamura, S., Murata, G., Koyama, T., 1964. Colored Illustrations of Herbaceous Plants of Japan Vol.3. Hoikusha. Osaka. (in Japanese).

Kleijn, D., Rundlöf, M., Scheper, J., Smith, H.G., Tscharntke, T., 2011. Does conservation on farmland contribute to halting the biodiversity decline? Trends Ecol. Evol. 26, 474-481. 
529

530

531

532

533

534

535

536

537

538

539

540

541

542

543

544

545

546

547

548

549

550

551

552

Koyanagi, T.F., Furukawa, T., 2013. Nation-wide agrarian depopulation threatens semi-natural grassland species in Japan: Sub-national application of the Red List Index. Biol. Conserv. 167, 1-8.

Krebs, J.R., Wilson, J.D., Bradbury, R.B., Siriwardena, G.M., 1999. The second silent spring? Nature 400, 611-612.

Leimu, R., Mutikainen, P., Koricheva, J., Fischer, M., 2006. How general are positive relationships between plant population size, fitness and genetic variation? J. Ecol. 94, 942-952.

Mantel, N., 1967 The detection of disease clustering and a generalized regression approach. Cancer Res. 27, 209-220.

Marchi, C., Andersen, L.W., Damgaard, C., Olsen, K., Jensen, T.S., Loeschcke, V., 2013. The Gene flow and population structure of a common agricultural wild species (Microtus agrestis) under different land management regimes. Heredity 111, 486-494.

Martin, A.C., 1946. The comparative internal morphology of seeds. Amer. Midl. Nat. 36, $513-660$.

McNeely, J.A., Gadgil, M., Leveque, C., Padoch, C., Redford, K., 1995. Human influences on biodiversity, in: Heywood, V.H.R., Watson, T. (Eds.), Global Biodiversity Assessment. Cambridge University Press, Cambridge, pp. 711-821.

Milligan, B., 1992. Plant DNA isolation, in: Hoelzel, A. R. (Ed.), Molecular Genetic Analysis of Populations: a Practical Approach. IRL Press, Oxford, pp. 59-88.

Ministry of the Environment Government of Japan, 2012. The Red List of Vascular Plants of Japan. https://www.env.go.jp/press/file_view.php?serial=20557\&hou_id=15619 (accessed 01.03.14).

Nakahama, N., Kaneko, S., Hayano, A., Isagi, Y., Inoue-Murayama, M., Tominaga, T., 2012. 
Development of microsatellite markers for the endangered grassland species Vincetoxicum pycnostelma (Apocynaceae), using next-generation sequencing technology. Conserv. Genet. Resour. 4, 669-671.

Nakahama, N., Miura, R., Tominaga. T., 2013a. Preliminary observations of insect visitation to flowers of Vincetoxicum pycnostelma (Apocynaceae: Asclepiadoideae), an endangered species in Japan. J. Entomol. Sci. 48, 151-160.

Nakahama N., Ushimaru, A., Isagi, Y., 2013b. Reproductive traits and flower visitors of Vincetoxicum pycnostelma Kitag. in Nishitani area of Takarazuka City, Hyogo Prefecture. B. Kansai Organ. Nature Conserv. 35, 115-123. (in Japanese with English summary)

Nei, M., Tajima, F., Tateno, Y., 1983. Accuracy of estimated phylogenetic trees from molecular data. J. Mol. Evol. 19, 153-170.

Nei, M., 1987. Molecular Evolutionary Genetics. Columbia University Press, New York.

Peakall, R., Smouse, P.E., 2006. GENALEX 6: genetic analysis in Excel. Population genetic software for teaching and research. Mol. Ecol. Notes 6, 288-295.

Potts, S. G., Petanidou, T., Roberts, S., O’Toole, C., Hulbert, A., Willmer, P., 2006. Plant-pollinator biodiversity and pollination services in a complex Mediterranean landscape. Biol. Conserve. 129, 519-529.

Pöyry, J., Luoto, M., Paukkunen, J., Pykälä, J., Raatikainen, K., Kuussaari, M., 2006. Different responses of plants and herbivore insects to a gradient of vegetation height: an indicator of the vertebrate grazing intensity and successional age. Oikos 115, 401-412.

Pritchard, J.K., Wen, X., Falshu, D., 2009. Documentation for STRUCTURE ver. 2.3. University of Chicago, Chicago.

Raunkiaer, C., 1934. The life-forms of plants and statistical plant geography. Oxford University Press, Oxford. 
R Development Core Team. 2012. R: A language and environment for statistical computing. R Foundation for Statistical Computing, Vienna, Austria. http://www.R-project.org/ (accessed 01.10.12).

Rüdinger, M.C.D., Glaeser, J., Hebel, I., Dounavi, A., 2008. Genetic structures of common ash (Fraxinus excelsior) populations in Germany at sites differing in water regimes. Can. J. For. Res. 38, 1199-1210.

Shimono, Y., Kurokawa, S., Nishida, T., Ikeda, H., Futagami, N., 2013a. Phylogeography based on intraspecific sequence variation in chloroplast DNA of Miscanthus sinensis (Poaceae), a native pioneer grass in Japan. Botany 91, 449-456.

Shimono, Y., Hayakawa, H., Kurokawa, S., Nishida, T., Ikeda, H., Futagami, N., $2013 b$. Phylogeography of Mugwort (Artemisia indica), a Native Pioneer Herb in Japan. J. Heredity 104, 830-841.

Söderström, B., Svensson, B., Vessby, K., Glimskär, A., 2001. Plants, insects and birds in semi-natural pastures in relation to local habitat and landscape factors. Biodivers. Conserv. 10, 1839-1863.

Tilman, D., Fargione, J., Wolff, B., D’Antonio, C., Dobson, A., Howarth, R., Schindler, D., Schlesinger, W.H., Simberloff, D., Swackhamer, D., 2001. Forecasting agriculturally driven global environmental change. Science 292, 281-284.

Tscharntke, T., Klein, A.M., Kruess, A., Steffan-Dewenter, I., Thies, C., 2005. Landscape perspectives on agricultural intensification and biodiversity - ecosystem service management. Ecol. Lett. 8, 857-874.

Uematsu, Y., Koga, T., Mitsuhashi, H., Ushimaru. A., 2010. Abandonment and intensified use of agricultural land decrease habitats of rare herbs in semi-natural grasslands. Agric. Ecosyst. Environ. 135, 304-309. 
601 Uematsu, Y., Ushimaru, A., 2013. Topography- and management-mediated resource

602 gradients maintain rare and common plant diversity around paddy terraces. Ecol. Appl.

$603 \quad 23,1357-1366$.

604 Uchida, K. and Ushimaru, A., 2014. Biodiversity declines due to abandonment and

605 intensification of agricultural lands: patterns and mechanisms. Ecol. Monograph 84, $606 \quad 637-658$.

607 Willems, J.H., Bik, L.P.M., 1998. Restoration of high species density in calcareous grassland:

608 the role of seed rain and soil seed bank. Appl. Veg. Sci. 1, 91-100.

609 Wyatt, R., Broyles, S.B., 1994. Ecology and evolution of reproduction in milkweeds. Annu.

610 Rev. Ecol. Syst. 25, 423-441.

611 Yamashiro, T., Yamashiro, A., Yokoyama, J., Maki, M., 2008. Morphological aspects and

612 phylogenetic analysis of pollination systems in the Typhora-Vincetoxicum complex

613 (Apocynaceae - Asclepiadoideae) in Japan. Biol. J. Linnean Soc. 93, 325-341.

614 Young, A. G., Pickup, M., 2010. Low S-allele numbers limit mate availability, reduce seed set

615 and skew fitness in small populations of a self-incompatible plant. J. Appl. Ecol. 47, $616 \quad 541-548$.

617 Zaghloul, M., Reisch, C., Poschlod, P., 2013. Soil seed bank contributes significantly to 618 genetic variation of Hypericum sinaicum in a changing environment. Plant Syst. Evol. $619 \quad 299,1819-1828$.

620 Zechmeister, H.G., Schmitzberger, I., Steurer, B., Peterseil, J., Wrbka, T., 2003. The influence 621 of land-use practices and economics on plant species richness in meadows. Biol. Conserv. $622114,165-177$.

623 Zhou, Y.F., Hang, Y.Z., Zhou, L.L., Wang, K.C., 2003. The germination characteristics of

624 Cynanchum paniculatum seeds. J. Plant Resourc. Environ. 12, 35-38. 


\section{Appendix}

627 Additional supplemental material can be found in the online version of this article.

628

629 Appendix A1. The protocol of microsatellite analysis.

630

631 Appendix A2. The protocol of random resampling for genetic analysis.

632

633

Table A1. Mean temperature and total precipitation during the growing season of $V$.

634

pycnostelma (April to October) at each site.

635

636

Table A2. Reproductive success and vegetative growth of each $V$. pycnostelma population.

637

638

Table A3. Characteristics of two novel microsatellite loci.

639

640

Table A4. Genetic diversity (Allelic richness and expected heterozygosity) calculated from

641 all samples and randomly selected samples.

642

643

Table A5. Selected models for the reproductive success of $V$. pycnostelma.

644

645

Table A6. Estimated coefficients of explanatory variables in the best GLMMs for the

vegetative growth parameters of $V$. pycnostelma.

647

648 Table A7. Selected models for the vegetative success of $V$. pycnostelma. 
649

650 Table A8. Selected models for the genetic diversity of V. pycnostelma.

651

652 Table A9. Presence/absence of other coexisting rare endangered species for each population 653 of V. pycnostelma.

654

655 Table A10. Estimated coefficients of explanatory variables in the best GLMMs for coexisting 656 endangered species.

657

658 Figure A1. Locations of V. pycnostelma study populations.

659

660 Figure A2. Relationships between genetic distance and geographic distance.

661

662 FigureA3. Results of STRUCTURE analysis 
663 Table 1. Characteristics of the fifteen V. pycnostelma populations examined in this study. Population ID, area ( $\left.\mathrm{m}^{2}\right)$, population size, the mean 664 vegetation height, and mowing practice (the presence or absence of the mowing event during the each period and total number of mowing events 665 per one year) are indicated for each population. Mowing timings were divided into five groups depending on mowing practice (see text for

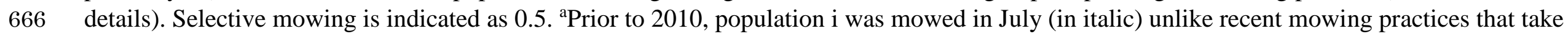

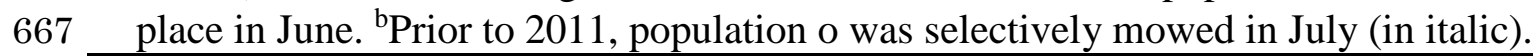

\begin{tabular}{|c|c|c|c|c|c|c|c|c|c|c|}
\hline \multirow[b]{2}{*}{ ID } & \multirow[b]{2}{*}{ Prefecture } & \multirow[b]{2}{*}{$\begin{array}{l}\text { Area } \\
\left(\mathrm{m}^{2}\right)\end{array}$} & \multirow[b]{2}{*}{$\begin{array}{l}\text { Population } \\
\text { size }\end{array}$} & \multirow[b]{2}{*}{$\begin{array}{c}\text { Mean } \\
\text { vegetation } \\
\text { height }(\mathrm{cm})\end{array}$} & \multicolumn{5}{|c|}{ Mowing events } & \multirow[b]{2}{*}{$\begin{array}{l}\text { Total number of } \\
\text { mowing events } \\
\text { per one year }\end{array}$} \\
\hline & & & & & $\begin{array}{l}\text { Pre growing } \\
\text { period } \\
\text { (Nov.-Mar.) }\end{array}$ & $\begin{array}{c}\text { Growing } \\
\text { period } \\
\text { (Apr.-May) }\end{array}$ & $\begin{array}{c}\text { Early } \\
\text { flowering } \\
\text { period } \\
\text { (Jun.) } \\
\end{array}$ & $\begin{array}{c}\text { Flowering } \\
\text { peak } \\
\text { (Jul.) } \\
\end{array}$ & $\begin{array}{l}\text { Late flowering } \\
\text { and fruiting } \\
\text { period } \\
\text { (Aug.-Sept.) }\end{array}$ & \\
\hline $\mathrm{a}$ & Gifu & 67.7 & 92 & 9.58 & 0 & 0 & 0 & 1 & 0 & 1 \\
\hline $\mathrm{b}$ & Aichi & 333.3 & 260 & 54.17 & 1 & 0 & 1 & 0 & 0 & 2 \\
\hline c & Shiga & 1486.7 & 300 & 60.83 & 1 & 0 & 1 & 0 & 0 & 2 \\
\hline d & Osaka & 320.0 & 220 & 12.92 & 0 & 0 & 1 & 0 & 1 & 2 \\
\hline e & Osaka & 154.18 & 100 & 31.67 & 0 & 0 & 0 & 0 & 1 & 1 \\
\hline $\mathrm{f}$ & Hyogo & 277.73 & 180 & 66.25 & 1 & 1 & 0.5 & 0 & 0.5 & 4 \\
\hline g & Hyogo & 200.48 & 200 & 40.83 & 0 & 0 & 1 & 0 & 0 & 1 \\
\hline h & Hyogo & 180.06 & 42 & 38.75 & 0 & 0 & 0 & 0 & 0.5 & 2 \\
\hline i & Hyogo & 332.48 & 58 & 43.75 & 0 & 0 & 1 & $1^{\mathrm{a}}$ & 0 & 1 \\
\hline j & Hyogo & 75.0 & 5 & 34.58 & 0 & 1 & 0 & 1 & 0 & 2 \\
\hline $\mathrm{k}$ & Hyogo & 430.6 & 24 & 38.75 & 1 & 1 & 1 & 0 & 1 & 4 \\
\hline 1 & Hyogo & 340.9 & 30 & 86.25 & 1 & 0 & 0 & 0 & 0 & 1 \\
\hline $\mathrm{m}$ & Hyogo & 237.6 & 100 & 43.33 & 1 & 1 & 1 & 0 & $1+0.5$ & 5 \\
\hline$n$ & Hyogo & 823.0 & 60 & 52.5 & 1 & 0 & 0 & 0 & 0 & 1 \\
\hline 0 & Hyogo & 753.9 & 50 & 34.17 & 1 & 0 & 0 & $1\left(0.5^{b}\right)$ & 0 & 3 \\
\hline
\end{tabular}


672 Table 2. Genetic diversity measurements of fourteen $V$. pycnostelma populations.

673 No. of samples; numbers outside and in parentheses indicate the numbers of samples 674 used for genetic analysis and all samples, respectively, $A$; number of alleles per locus,

$675 A_{\mathrm{R}}$; allelic richness, $H_{\mathrm{O}}$; observed heterozygosity, $H_{\mathrm{E}}$; expected heterozygosity,

$676 \quad F_{\text {IS; inbreeding coefficient }}$

\begin{tabular}{lcccccr}
\hline Population ID & $\begin{array}{c}\text { No. of } \\
\text { samples }\end{array}$ & $A$ & $A_{\mathrm{R}}$ & $H_{\mathrm{O}}$ & $H_{\mathrm{E}}$ & \multicolumn{1}{c}{$F_{\mathrm{IS}}$} \\
\hline $\mathrm{a}$ & $22(27)$ & 6.78 & 5.86 & 0.758 & 0.702 & -0.107 \\
$\mathrm{~b}$ & $22(50)$ & 7.56 & 6.44 & 0.737 & 0.742 & -0.012 \\
$\mathrm{c}$ & $22(58)$ & 8.44 & 7.10 & 0.717 & 0.763 & 0.036 \\
$\mathrm{~d}$ & $22(28)$ & 6.89 & 5.78 & 0.753 & 0.694 & -0.115 \\
$\mathrm{e}$ & $22(26)$ & 8.00 & 6.66 & 0.732 & 0.745 & -0.012 \\
$\mathrm{f}$ & $22(22)$ & 8.44 & 6.95 & 0.742 & 0.754 & -0.006 \\
$\mathrm{~g}$ & $22(54)$ & 8.44 & 7.08 & 0.773 & 0.759 & -0.041 \\
$\mathrm{~h}$ & $22(35)$ & 8.67 & 7.09 & 0.808 & 0.781 & -0.056 \\
$\mathrm{i}$ & $22(30)$ & 4.67 & 4.33 & 0.652 & 0.621 & -0.052 \\
$\mathrm{j}$ & - & - & - & - & - & \\
$\mathrm{k}$ & $16(16)$ & 7.56 & 6.75 & 0.701 & 0.748 & 0.030 \\
$\mathrm{l}$ & $12(12)$ & 7.78 & 7.78 & 0.843 & 0.783 & -0.116 \\
$\mathrm{~m}$ & $22(22)$ & 7.22 & 6.22 & 0.798 & 0.746 & -0.097 \\
$\mathrm{n}$ & $22(29)$ & 9.44 & 7.79 & 0.793 & 0.795 & -0.019 \\
$\mathrm{o}$ & $22(23)$ & 8.44 & 7.02 & 0.758 & 0.760 & -0.020 \\
\hline
\end{tabular}


684 Table 3. Estimated coefficients of explanatory variables in the best generalized linear mixed model for the pollination success, reproductive success and genetic diversity of $V$. pycnostelma. Bold numbers indicate that the $95 \%$ confidence interval (CI) for the partial regression coefficient did not include zero. AIC: Akaike's information criterion.

\begin{tabular}{|c|c|c|c|c|c|c|c|}
\hline \multirow{2}{*}{\multicolumn{2}{|c|}{ Response variable }} & \multirow{2}{*}{ Explanatory variable } & \multirow{2}{*}{ Coefficient } & \multicolumn{2}{|c|}{$95 \% \mathrm{CI}$} & \multicolumn{2}{|c|}{ AIC of the model } \\
\hline & & & & Lower & Upper & Null & Best \\
\hline \multirow{4}{*}{$\begin{array}{l}\text { Pollination } \\
\text { success }\end{array}$} & \multirow{2}{*}{$\begin{array}{l}\text { No. of pollinia- } \\
\text { removed flowers }\end{array}$} & Area $\left(\mathrm{m}^{2}\right)$ & 0.001 & 0.001 & 0.002 & \multirow[t]{2}{*}{449.6} & \multirow[t]{2}{*}{442.8} \\
\hline & & Intercept & -0.027 & -0.298 & 0.245 & & \\
\hline & \multirow{2}{*}{$\begin{array}{l}\text { No. of pollinated } \\
\text { flowers }\end{array}$} & Area $\left(\mathrm{m}^{2}\right)$ & 0.001 & -0.000 & 0.001 & \multirow[t]{2}{*}{254.9} & \multirow[t]{2}{*}{254.3} \\
\hline & & Intercept & -2.457 & -2.885 & -2.028 & & \\
\hline \multirow{11}{*}{$\begin{array}{l}\text { Reproductive } \\
\text { success }\end{array}$} & \multirow{5}{*}{$\begin{array}{l}\text { No. of } \\
\text { inflorescences in } \\
2013\end{array}$} & Mowing during Apr. and May. & 1.276 & 0.647 & 1.905 & \multirow[t]{5}{*}{1965.9} & \multirow[t]{5}{*}{1953.5} \\
\hline & & Mowing in Jul. & -1.841 & -2.519 & -1.162 & & \\
\hline & & Mowing during Aug. and Sep. & -1.718 & -2.337 & -1.098 & & \\
\hline & & Total precipitation & 0.003 & 0.001 & 0.006 & & \\
\hline & & Intercept & -1.830 & -4.38 & 0.719 & & \\
\hline & \multirow{6}{*}{$\begin{array}{l}\text { No. of fruits in } 2012 \\
\text { and } 2013\end{array}$} & Mowing during Nov. to Mar. & 0.889 & 0.566 & 1.212 & \multirow[t]{6}{*}{879.7} & \multirow[t]{6}{*}{858.1} \\
\hline & & Mowing in Jul. & -1.912 & -2.533 & -1.291 & & \\
\hline & & Mowing during Aug. and Sep. & -0.851 & -1.176 & -0.526 & & \\
\hline & & Area $\left(\mathrm{m}^{2}\right)$ & -0.0005 & -0.001 & -0.000 & & \\
\hline & & Mean temperature & -0.426 & -0.600 & -0.252 & & \\
\hline & & Intercept & 8.527 & 4.897 & 12.157 & & \\
\hline \multirow{8}{*}{$\begin{array}{l}\text { Genetic } \\
\text { diversity }\end{array}$} & \multirow{4}{*}{$\begin{array}{l}H_{\mathrm{E}} \\
\text { (arcsin-transformed) }\end{array}$} & Mowing in Jul. & -0.172 & -0.239 & -0.105 & \multirow[t]{4}{*}{-128.1} & \multirow[t]{4}{*}{-140.1} \\
\hline & & Mowing during Aug. and Sep. & -0.060 & -0.105 & -0.014 & & \\
\hline & & Population size & -0.0003 & -0.0001 & -0.0000 & & \\
\hline & & Intercept & 0.946 & 0.842 & 1.049 & & \\
\hline & \multirow[t]{4}{*}{ Allelic richness } & Mowing in Jul. & -2.438 & -3.155 & -1.721 & \multirow[t]{4}{*}{474.3} & \multirow[t]{4}{*}{460.2} \\
\hline & & Mowing during Aug. and Sep. & -1.010 & -1.498 & -0.521 & & \\
\hline & & Population size & -0.004 & -0.007 & -0.001 & & \\
\hline & & Intercept & 7.956 & 6.707 & 9.205 & & \\
\hline
\end{tabular}


688

689 Fig. 1. Relationship between pollination success and flowering timing. Bar plots indicate the 690 percentages of pollinia-removed flowers (a) and pollinated flowers (b) in inflorescences in 691 each 10-days period. Error bars indicate the standard errors.

692

693

Fig. 2. Comparison of reproductive success and genetic diversity among study populations:

694 mean numbers of inflorescences and fruits in 2013 (a) and mean expected heterozygosity

695 and allelic richness (b). Black circles represent populations mowed during July and

696 September. Grey circles represent populations mowed selectively during July and September.

697 Open circles represent populations mowed in other months. The bars indicate standard

698 errors.

699

700

701

702

703

704

705

706

707

708

709

710 
$711 \quad$ Fig. 1

(a)

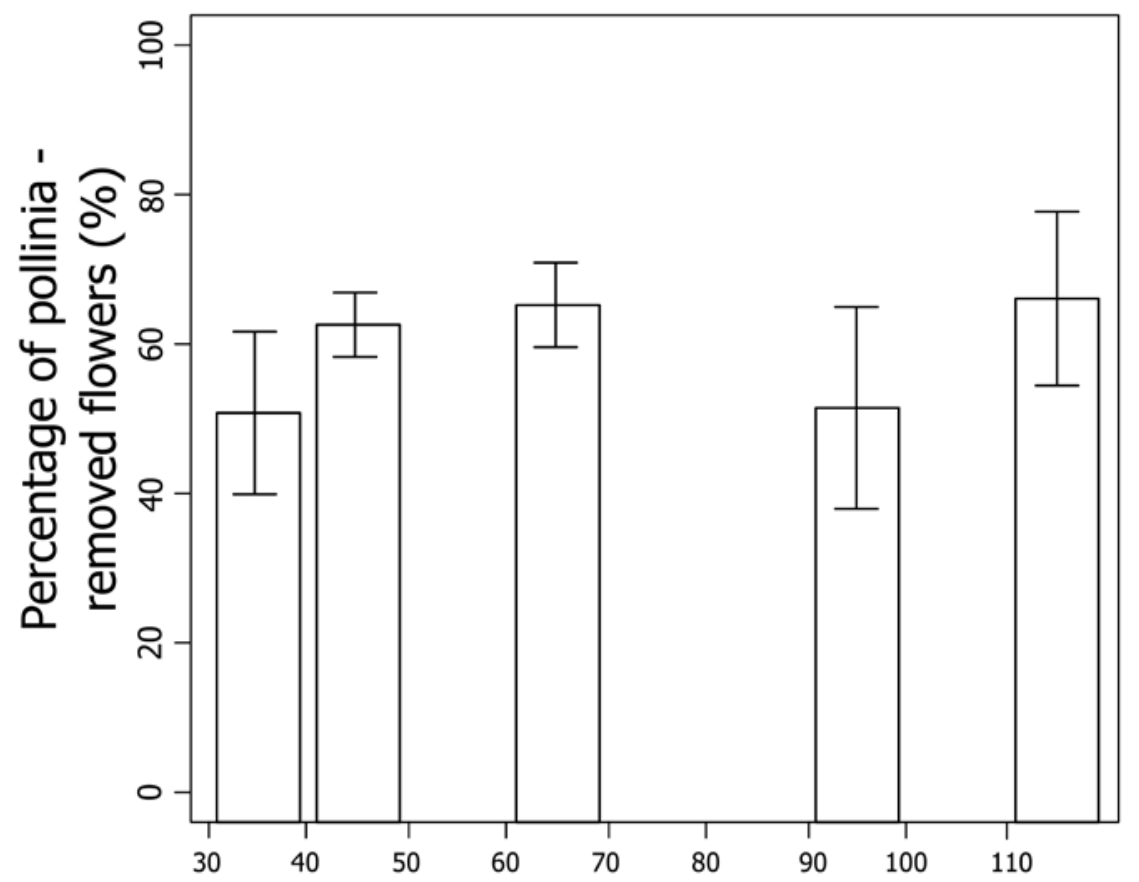

(b)

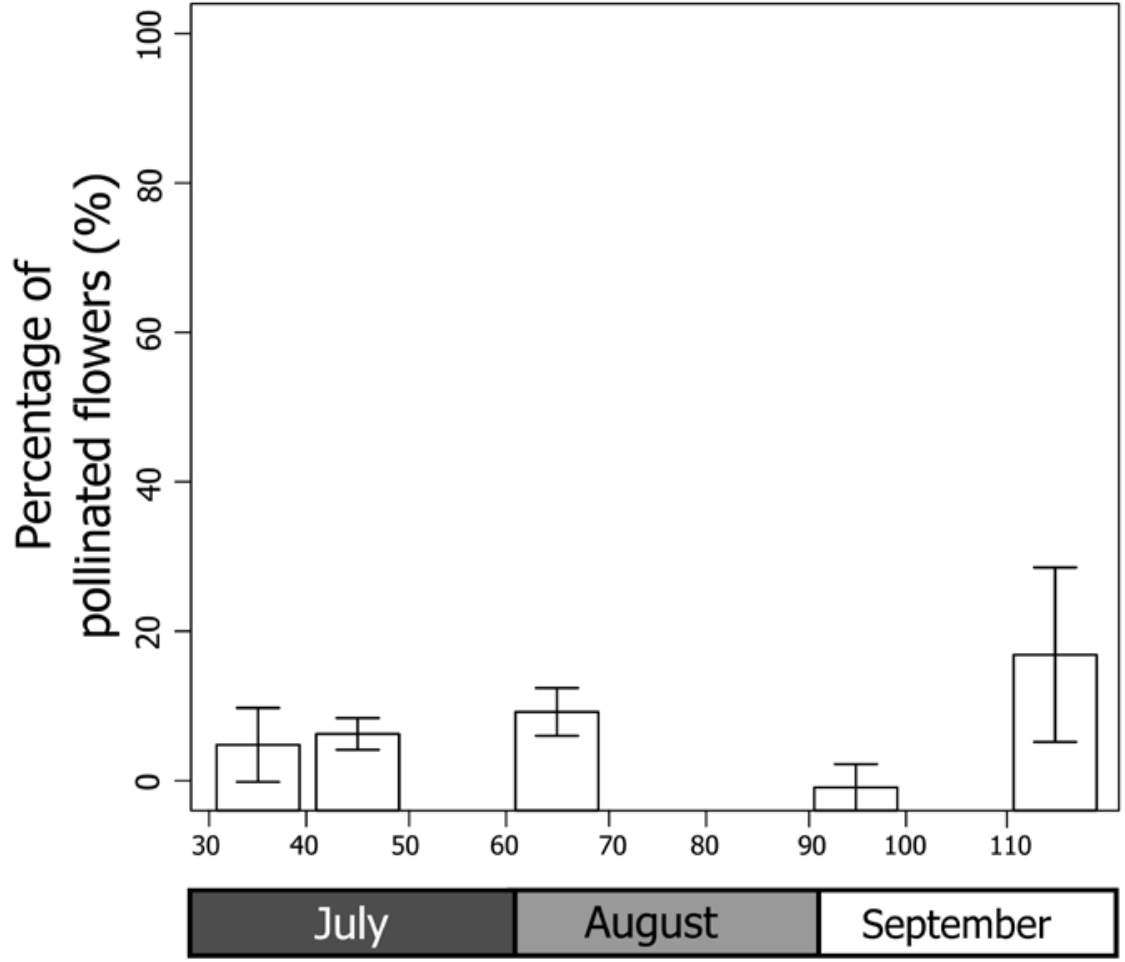

Number of days from 1st June 
$715 \quad$ Fig. 2

(a)

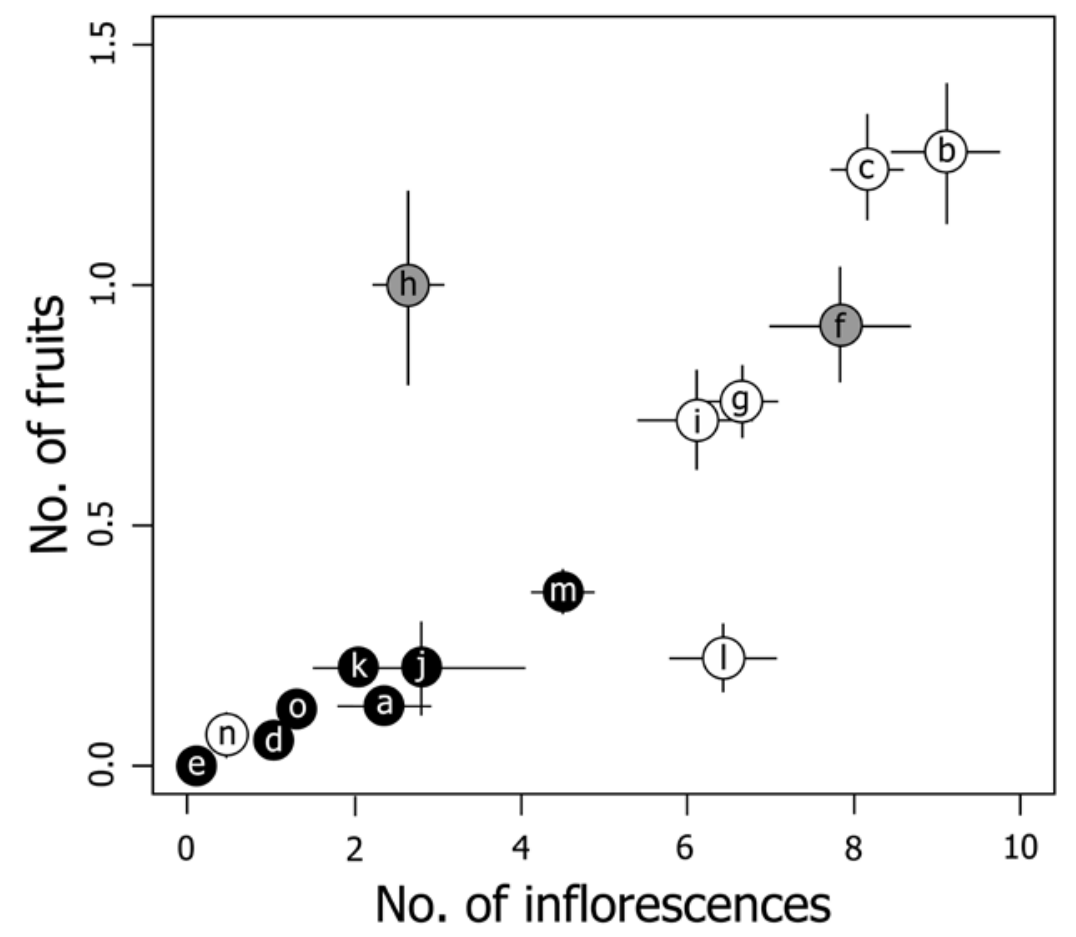

(b)

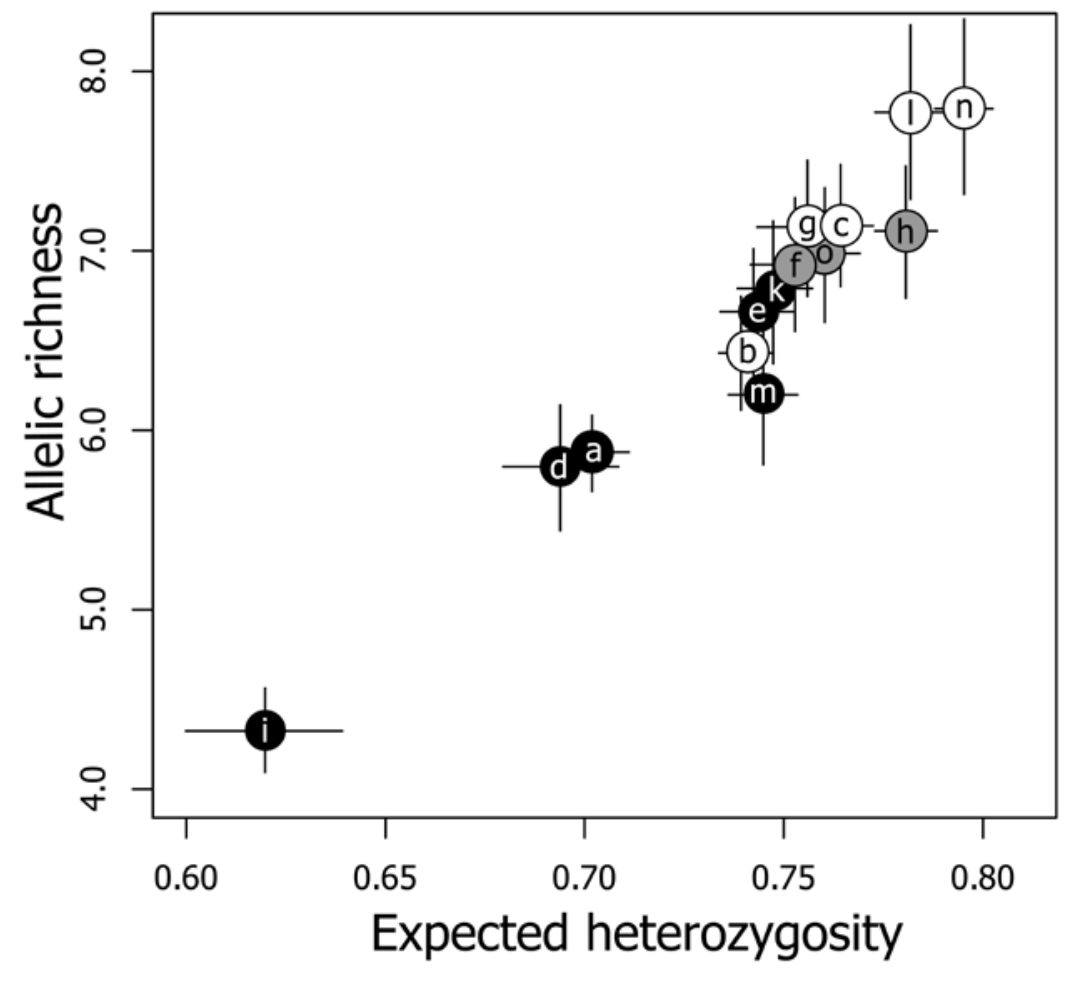


1

2

3

4

5

6

7

8

9

\section{Supplementary data}

\section{Appendix A. Supplementary Material and Methods}

\section{Appendix A1}

With the exception of Vpy025 and Vpy031, PCR amplifications were performed following the standard protocol of the Qiagen Multiplex PCR kit (Qiagen): the final $5 \mu \mathrm{L}$ volume contained $16 \mathrm{ng}$ of extracted DNA, $2.5 \mu \mathrm{L}$ of $2 \times$ Multiplex PCR Master Mix (Qiagen), and $0.2 \mu \mathrm{M}$ of each multiplexed primer. For

Vpy025 and Vpy031, the forward primer was synthesised using an M13 tag sequence (Vpy025: 5' -

CACGACGTTGTAAAACGAC-3' , Vpy031: 5’ -TGTGGAATTGTGAGCGG-3' ;

10 Boutin-Ganache et al., 2001). The PCR of the Vpy025 and Vpy031 reaction mixture had a final volume of $5 \mu \mathrm{L}$, which contained 16 ng of extracted DNA, $2.5 \mu \mathrm{L}$ of $2 \times$ Multiplex PCR Master Mix, $0.01 \mu \mathrm{M}$ of forward primer, $0.2 \mu \mathrm{M}$ of reverse primer, and $0.1 \mu \mathrm{M}$ of $\mathrm{M} 13$ (fluorescently labelled) primer. The PCR amplifications of all loci were performed using a GeneAmp PCR System 2700 thermal cycler (Applied Biosystems) with the following protocol: initial denaturation at $95^{\circ} \mathrm{C}$ for $15 \mathrm{~min}$, followed by 25 cycles of $30 \mathrm{~s}$ at $94^{\circ} \mathrm{C}, 1.5 \mathrm{~min}$ at $57^{\circ} \mathrm{C}, 1 \mathrm{~min}$ at $72^{\circ} \mathrm{C}$, and a final extension for $30 \mathrm{~min}$ at $60^{\circ} \mathrm{C}$. PCR product sizes were measured using an ABI PRISM 3130 Genetic Analyzer (Applied Biosystems, Foster City, California, USA) and GeneMapper (Applied Biosystems).

\section{Reference}

Boutin-Ganache, I., Raposo, M., Raymond, M., Deschepper, C.F., 2001. M13-tailed primers improve the reliability and usability of microsatellite analyses performed with two different allele sizing methods. Biotechniques 31, 24-26. 


\section{Appendix A2}

33 We randomly resampled 22 individuals for 10 populations with more than 22 samples (except sites f, $\mathrm{k}$,

$34 \mathrm{l}$ and $\mathrm{m}$ ) in order to avoid the effect of the variation in sample size among populations on genetic analyses. The random resampling was repeated for 1000 times from the all samples using $\mathrm{R}$ software (version 2.15.1; R Core Development Team, 2012) and 1000th resampling data set was used for the microsatellite analyses. In order to assess the validity of selected samples, we compared the allelic richness and Nei's unbiased expected heterozygosity calculated from the all samples ( $\mathrm{n}=23-58$ ) and the random selected samples $(\mathrm{n}=22)$ in 10 populations using the package hierfstat. In addition, the mean value and standard deviations were calculated using the 1000 resampling data sets. There were very little differences in the genetic variables among the data sets (Table A4).

42 
64 Table A1. Mean temperature and total precipitation during the growing season of $V$.

65 pycnostelma (April to October) in 1981-2010, 2012, and 2013 in each site. The data were

66 collected from nearest AMeDAS (Automated Meteorological Data Acquisition System;

67 http://www.data.jma.go.jp/obd/stats/etrn/index.php) point for each study site.

\begin{tabular}{|c|c|c|c|c|c|c|c|}
\hline \multirow{2}{*}{ ID } & \multicolumn{3}{|c|}{ Temperature $\left({ }^{\circ} \mathrm{C}\right)$} & \multicolumn{3}{|c|}{ precipitation (mm) } & \multirow{2}{*}{ Point } \\
\hline & 1981-2010 & 2012 & 2013 & 1981-2010 & 2012 & 2013 & \\
\hline $\mathrm{a}$ & 20.9 & 21.5 & 22.0 & $1,350.5$ & $1,102.0$ & $1,230.5$ & Mino-Kamo \\
\hline b & 20.9 & 21.5 & 22.0 & $1,350.5$ & $1,102.0$ & $1,230.5$ & Mino-Kamo \\
\hline C & 19.8 & 19.6 & 19.8 & $1,085.2$ & $1,223.0$ & $1,242.0$ & Maibara \\
\hline d & 21.8 & 22.7 & 22.9 & 869.9 & 896.5 & 842.0 & Sakai \\
\hline e & 21.2 & 21.5 & 21.9 & 917.7 & 859.0 & $1,008.5$ & Kumatori \\
\hline $\mathrm{f}$ & 20.0 & 20.4 & 20.4 & 942.2 & 816.0 & $1,059.5$ & Sanda \\
\hline g & 20.0 & 20.4 & 20.4 & 942.2 & 816.0 & $1,059.5$ & Sanda \\
\hline $\mathrm{h}$ & 20.0 & 20.4 & 20.4 & 942.2 & 816.0 & $1,059.5$ & Sanda \\
\hline $\mathrm{i}$ & 20.0 & 20.4 & 20.4 & 942.2 & 816.0 & $1,059.5$ & Sanda \\
\hline j & 20.6 & 21.2 & 21.2 & 884.9 & 823.0 & $1,080.0$ & Miki \\
\hline $\mathrm{k}$ & 22.4 & 22.9 & 23.0 & 918.8 & 855.0 & $1,014.5$ & Kobe \\
\hline 1 & 22.4 & 22.9 & 23.0 & 918.8 & 855.0 & $1,014.5$ & Kobe \\
\hline $\mathrm{m}$ & 21.4 & 21.6 & 21.8 & 818.7 & 951.0 & $1,209.0$ & Gunge \\
\hline $\mathrm{n}$ & 19.1 & 19.6 & 19.7 & $1,481.4$ & $1,563.5$ & $1,699.5$ & Ikuno \\
\hline o & 20.3 & 21.2 & 21.1 & $1,078.7$ & 958.0 & $1,252.5$ & Toyo-Oka \\
\hline
\end{tabular}


68 Table A2. Reproductive success (number of inflorescences and fruits per ramets) and vegetative growth (maximum stem height and stem diameter at ground 69 level) of each V. pycnostelma population. The numbers of fruits and the maximum stem height were measured from September to October in 2012 and 2013.

70 The number of inflorescences and stem diameter at ground level of the tallest stem were measured from September to October in 2013.

\begin{tabular}{|c|c|c|c|c|c|c|c|c|}
\hline \multirow[b]{3}{*}{ Population ID } & & & \multicolumn{3}{|c|}{ Reproductive success } & \multicolumn{3}{|c|}{ Vegetative growth } \\
\hline & \multicolumn{2}{|c|}{$\begin{array}{c}\text { No. of examined } \\
\text { ramets }\end{array}$} & $\begin{array}{c}\text { Mean no. of } \\
\text { inflorescences } \\
\text { per ramets } \\
\end{array}$ & \multicolumn{2}{|c|}{$\begin{array}{l}\text { Mean no. of fruits } \\
\text { per ramets }\end{array}$} & \multicolumn{2}{|c|}{$\begin{array}{l}\text { Mean maximum } \\
\text { stem height }(\mathrm{cm})\end{array}$} & \multirow{2}{*}{$\begin{array}{c}\text { Mean stem diameter } \\
\text { at ground level (mm) } \\
2013 \\
\end{array}$} \\
\hline & 2012 & 2013 & 2013 & 2012 & 2013 & 2012 & 2013 & \\
\hline $\mathrm{a}$ & 25 & 25 & 2.32 & 0.00 & 0.12 & 25.2 & 40.7 & 0.95 \\
\hline b & 25 & 25 & 9.04 & 0.92 & 1.28 & 57.8 & 62.8 & 1.39 \\
\hline c & - & 25 & 8.16 & - & 1.24 & - & 59.2 & 1.54 \\
\hline $\mathrm{d}$ & - & 25 & 0.92 & - & 0.04 & - & 29.6 & 0.72 \\
\hline e & - & 25 & 0.08 & - & 0.00 & - & 24.0 & 0.77 \\
\hline $\mathrm{f}$ & 22 & 25 & 7.84 & 1.14 & 0.92 & 54.8 & 63.6 & 1.52 \\
\hline g & 25 & 25 & 6.64 & 0.76 & 0.76 & 54.8 & 62.7 & 1.43 \\
\hline $\mathrm{h}$ & 15 & 13 & 2.62 & 0.53 & 1.00 & 60.5 & 50.1 & 1.12 \\
\hline $\mathrm{i}$ & - & 25 & 6.04 & - & 0.72 & - & 55.9 & 1.22 \\
\hline j & 5 & 5 & 2.80 & 0.00 & 0.20 & 31.8 & 34.0 & 1.24 \\
\hline $\mathrm{k}$ & 11 & 24 & 2.08 & 0.30 & 0.20 & 40.5 & 40.6 & 1.12 \\
\hline l & - & 9 & 6.44 & - & 0.22 & - & 82.4 & 2.26 \\
\hline $\mathrm{m}$ & 25 & 25 & 4.52 & 0.36 & 0.36 & 27.4 & 49.0 & 1.18 \\
\hline $\mathrm{n}$ & 20 & 20 & 0.50 & 0.05 & 0.10 & 35.8 & 31.0 & 1.22 \\
\hline 0 & 20 & 25 & 1.28 & 0.20 & 0.12 & 33.0 & 28.3 & 1.07 \\
\hline
\end{tabular}




\begin{tabular}{|c|c|c|c|c|c|c|c|c|}
\hline Locus & Repeat motif & Primer sequence (5'-3') & $T_{\mathrm{a}}\left({ }^{\circ} \mathrm{C}\right)$ & Size range (bp) & $A$ & $H_{\mathrm{O}}$ & $H_{\mathrm{E}}$ & Accession No. \\
\hline \multirow[t]{2}{*}{ Vpy 025} & $(\mathrm{GAT})_{8}$ & CCACTCTGCGTTTGGACTTG & 57 & $232-265$ & 7 & 0.741 & 0.740 & AB948217 \\
\hline & & CGTTCCСTAACATATCGCGG & & & & & & \\
\hline \multirow[t]{2}{*}{ Vpy 031} & $(\mathrm{AT})_{11}$ & ATGTTGGCATGTTCTAAGGC & 57 & 168-188 & 7 & 0.759 & 0.717 & AB948218 \\
\hline & & AGCAAGTAGGCAAACGGTG & & & & & & \\
\hline
\end{tabular}

Table A3. Characteristics of two novel microsatellite loci for V. pycnostelma and their variability. Deviation from Hardy-Weinberg equilibrium (HWE) and linkage disequilibrium between loci were tested using FSTAT ver. 2.9.3 software (Goudet, 2001) with genotype data of site c. Significance levels were tested using Bonferroni correction for multiple testing. No significant deviations from HWE were detected for either locus. There was no evidence of significant linkage disequilibrium between the two loci. $T_{\mathrm{a}}$, annealing temperature; $A$, number of alleles; $H_{\mathrm{O}}$, observed heterozygosity; $H_{\mathrm{E}}$, expected heterozygosity.

\section{1}

82

83

84

85

86

87

88

89

90

91

92

93

94

95

96

97

98

99

100 
101 Table A4. Genetic diversity indices calculated from 1000 resampling data sets, 1000th resampling and full data sets. Resampling was not conducted for populations f, k, l and m, because their sample size were equal or fewer than 22. AR; Allelic richness; $H_{\mathrm{E}}$; expected heterozygosity

\begin{tabular}{|c|c|c|c|c|c|c|}
\hline \multirow[t]{2}{*}{ Population ID } & \multicolumn{2}{|c|}{$\begin{array}{l}1000 \text { resampling data sets } \\
\qquad(\mathrm{n}=22)\end{array}$} & \multicolumn{2}{|c|}{$\begin{array}{l}\text { 1000th resampling data set } \\
\qquad(\mathrm{n}=22)\end{array}$} & \multicolumn{2}{|c|}{$\begin{array}{l}\text { Full data set } \\
(\mathrm{n}=12-58)\end{array}$} \\
\hline & $A_{\mathrm{R}}($ Mean $\pm \mathrm{SD})$ & $H_{\mathrm{E}}($ Mean $+\mathrm{SD})$ & $A_{\mathrm{R}}($ Mean) & $H_{\mathrm{E}}$ (Mean) & $A_{R}($ Mean $)$ & $H_{\mathrm{E}}($ Mean $)$ \\
\hline $\mathrm{a}$ & $5.84 \pm 0.12$ & $0.703 \pm 0.0005$ & 5.86 & 0.702 & 5.85 & 0.703 \\
\hline b & $6.38 \pm 0.21$ & $0.736 \pm 0.0121$ & 6.44 & 0.742 & 6.38 & 0.735 \\
\hline c & $7.06 \pm 0.22$ & $0.769 \pm 0.0126$ & 7.10 & 0.763 & 7.06 & 0.769 \\
\hline d & $6.02 \pm 0.16$ & $0.714 \pm 0.0082$ & 5.78 & 0.694 & 6.03 & 0.715 \\
\hline e & $6.74 \pm 0.13$ & $0.745 \pm 0.0054$ & 6.66 & 0.745 & 6.75 & 0.746 \\
\hline $\mathrm{f}$ & no resampling & no resampling & no resampling & no resampling & 6.95 & 0.754 \\
\hline g & $7.13 \pm 0.20$ & $0.779 \pm 0.0107$ & 7.08 & 0.759 & 7.14 & 0.779 \\
\hline $\mathrm{h}$ & $6.97 \pm 0.20$ & $0.781 \pm 0.0072$ & 7.09 & 0.781 & 6.97 & 0.781 \\
\hline i & $4.44 \pm 0.09$ & $0.638 \pm 0.0089$ & 4.33 & 0.621 & 4.44 & 0.638 \\
\hline $\mathrm{k}$ & no resampling & no resampling & no resampling & no resampling & 6.75 & 0.748 \\
\hline 1 & no resampling & no resampling & no resampling & no resampling & 7.78 & 0.783 \\
\hline $\mathrm{m}$ & no resampling & no resampling & no resampling & no resampling & 6.22 & 0.746 \\
\hline $\mathrm{n}$ & $7.52 \pm 0.15$ & $0.781 \pm 0.0081$ & 7.79 & 0.795 & 7.52 & 0.781 \\
\hline 0 & $7.02 \pm 0.08$ & $0.760 \pm 0.0042$ & 7.02 & 0.76 & 7.02 & 0.761 \\
\hline
\end{tabular}

103 
113 Table A5. Results of model selections for the reproductive success of $V$. pycnostelma based on AIC. Estimated coefficient of each explanatory variable, AICs 114 and $\triangle$ AICs (the difference between each AIC value and the smallest value) are indicated for the top ten models with lower AICs. Bold numbers indicate that the 115 95\% confidence interval (CI) for the partial regression coefficient did not include zero.

\begin{tabular}{|c|c|c|c|c|c|c|c|c|c|c|c|c|c|}
\hline & \multirow[b]{2}{*}{ Model } & \multirow[b]{2}{*}{ Intercept } & \multicolumn{5}{|c|}{ Mowing timing } & \multirow[b]{2}{*}{$\begin{array}{l}\text { Area } \\
\left(\mathrm{m}^{2}\right)\end{array}$} & \multirow[b]{2}{*}{$\begin{array}{c}\text { Population } \\
\text { size }\end{array}$} & \multirow[b]{2}{*}{$\begin{array}{c}\text { Mean } \\
\text { temperature }\end{array}$} & \multirow[b]{2}{*}{$\begin{array}{c}\text { Mean } \\
\text { precipitation }\end{array}$} & \multirow[b]{2}{*}{ AIC } & \multirow[b]{2}{*}{$\triangle \mathrm{AIC}$} \\
\hline & & & $\begin{array}{c}\text { During Apr. } \\
\text { and May }\end{array}$ & In Jun. & In Jul. & $\begin{array}{c}\text { During } \\
\text { Aug. and } \\
\text { Sep. }\end{array}$ & $\begin{array}{c}\text { During } \\
\text { Nov. to } \\
\text { Mar. }\end{array}$ & & & & & & \\
\hline \multicolumn{14}{|c|}{ The number of inflorescences } \\
\hline Best model & & -1.830 & 1.276 & & -1.841 & -1.718 & & & & & 0.003 & 1953.5 & - \\
\hline 2nd & & -1.656 & 1.211 & 0.416 & -1.492 & -1.709 & & & & & 0.003 & 1953.8 & 0.5 \\
\hline 3rd & & -2.100 & 1.154 & 0.469 & -1.572 & -1.731 & & -0.0004 & & & 0.003 & 1954.5 & 1.0 \\
\hline 4th & & -2.169 & 1.240 & & -1.930 & -1.734 & & -0.0003 & & & 0.004 & 1954.8 & 1.3 \\
\hline 5th & & -3.561 & 1.304 & & -1.905 & -1.790 & & & & 0.072 & 0.004 & 1955.2 & 1.7 \\
\hline 6th & & -1.721 & 1.301 & & -1.756 & -1.706 & & & 0.0006 & & 0.003 & 1955.3 & 1.8 \\
\hline 7th & & -1.942 & 1.298 & & -1.868 & -1.720 & -0.048 & & & & 0.003 & 1955.4 & 1.9 \\
\hline 8th & & 8.921 & & 1.148 & & -1.195 & 1.330 & -0.0014 & & -0.377 & & 1955.4 & 1.9 \\
\hline 9th & & -3.283 & 1.238 & 0.410 & -1.557 & -1.777 & & & & 0.067 & 0.003 & 1955.6 & 2.1 \\
\hline 10th & & -1.710 & 1.188 & 0.459 & -1.512 & -1.717 & & & -0.0004 & & 0.003 & 1955.8 & 2.3 \\
\hline \multicolumn{14}{|c|}{ The number of fruits } \\
\hline Best model & & 8.527 & & & -1.912 & -0.851 & 0.889 & -0.0005 & & -0.426 & & 858.8 & - \\
\hline 2nd & & 8.677 & & & -1.927 & -0.797 & 0.864 & -0.0006 & & -0.464 & 0.0007 & 859.4 & 0.8 \\
\hline 3rd & & 8.984 & & 0.234 & -1.693 & -0.805 & 0.910 & -0.0006 & & -0.457 & & 859.7 & 0.9 \\
\hline 4th & & 10.090 & -0.272 & & -1.872 & -0.669 & 1.06 & -0.0007 & & -0.502 & & 860.2 & 1.4 \\
\hline 5th & & 9.044 & & 0.191 & -1.745 & -0.767 & 0.884 & -0.0007 & & -0.484 & 0.0006 & 860.7 & 1.9 \\
\hline 6th & & 8.615 & & & -1.946 & -0.875 & 0.907 & -0.0005 & -0.0002 & -0.429 & & 860.8 & 2.0 \\
\hline 7th & & 10.82 & -0.311 & 0.249 & -1.631 & -0.593 & 1.104 & -0.0008 & & -0.546 & & 860.9 & 2.1 \\
\hline 8th & & 9.659 & -0.171 & & -1.897 & -0.691 & 0.976 & -0.0007 & & -0.508 & 0.0006 & 861.2 & 2.4 \\
\hline 9th & & 9.449 & & 0.306 & -1.755 & -0.885 & 0.990 & -0.0006 & -0.0009 & -0.476 & & 861.2 & 2.4 \\
\hline 10th & & 8.836 & & & -1.991 & -0.840 & 0.900 & -0.0006 & -0.0004 & -0.470 & 0.0007 & 861.3 & 2.5 \\
\hline
\end{tabular}


116 Table A6. Estimated coefficients of explanatory variables in the best generalized linear mixed model for vegetative growth of $V$. pycnostelma. 117 In 2012, data from nine populations were analyzed (sites c, d, e, i, l, and n were excluded); in 2013, data from 14 populations were used (site $n$ 118 was excluded). Bold numbers indicate that the 95\% confidence interval (CI) for the partial regression coefficient did not include zero. AIC, Akaike's 119 information criterion.

\begin{tabular}{|c|c|c|c|c|c|c|}
\hline \multirow[b]{2}{*}{ Response variable } & \multirow[b]{2}{*}{ Explanatory variable } & \multirow[b]{2}{*}{ Coefficient } & \multicolumn{2}{|c|}{ 95\% Confidence interval } & \multicolumn{2}{|c|}{ AIC } \\
\hline & & & Lower limit & Upper limit & Null model & Best model \\
\hline \multirow{6}{*}{$\begin{array}{l}\text { Stem diameter at } \\
\text { ground level in } 2013\end{array}$} & Mowing during Nov. to Mar. & 0.320 & 0.142 & 0.498 & 361.3 & 347.9 \\
\hline & Mowing during Apr. and May & 0.238 & -0.002 & 0.479 & & \\
\hline & Mowing in Jun. & -0.237 & -0.446 & -0.028 & & \\
\hline & Mowing in Jul. & -0.553 & -0.824 & -0.282 & & \\
\hline & Mowing during Aug. and Sep. & -0.568 & -0.769 & -0.368 & & \\
\hline & Intercept & 1.490 & 1.280 & 1.699 & & \\
\hline
\end{tabular}

120 
136 Table A7. Results of model selections for the vegetative growth of $V$. pycnostelma based on AIC. Estimated coefficients for selected explanatory variables, 137 AICs and $\triangle$ AICs (the difference between each AIC value and the smallest value) are indicated for the lowest ten models of AICs. Bold numbers indicate that 138 the $95 \%$ confidence interval (CI) for the partial regression coefficient did not include zero.

\begin{tabular}{|c|c|c|c|c|c|c|c|c|c|c|c|c|c|}
\hline & \multirow[b]{2}{*}{ Model } & \multirow[b]{2}{*}{ Intercept } & \multicolumn{5}{|c|}{ Mowing timing } & \multirow[b]{2}{*}{$\begin{array}{l}\text { Area } \\
\left(\mathrm{m}^{2}\right)\end{array}$} & \multirow[b]{2}{*}{$\begin{array}{c}\text { Population } \\
\text { size } \\
\end{array}$} & \multirow[b]{2}{*}{$\begin{array}{c}\text { Mean } \\
\text { temperature }\end{array}$} & \multirow[b]{2}{*}{$\begin{array}{c}\text { Mean } \\
\text { precipitation }\end{array}$} & \multirow[b]{2}{*}{ AIC } & \multirow[b]{2}{*}{$\triangle \mathrm{AIC}$} \\
\hline & & & $\begin{array}{c}\text { During Apr. } \\
\text { and May }\end{array}$ & In Jun. & In Jul. & $\begin{array}{c}\text { During } \\
\text { Aug. and } \\
\text { Sep. }\end{array}$ & $\begin{array}{c}\text { During } \\
\text { Nov. to } \\
\text { Mar. }\end{array}$ & & & & & & \\
\hline \multicolumn{14}{|c|}{ Stem diameters at ground level in 2013} \\
\hline Best model & & 1.490 & 0.238 & -0.237 & -0.553 & -0.568 & 0.320 & & & & & 347.9 & - \\
\hline 2nd & & 1.481 & & & -0.464 & -0.513 & 0.402 & & -0.0011 & & & 348.2 & 0.3 \\
\hline 3rd & & 1.532 & 0.193 & -0.183 & -0.565 & -0.575 & 0.340 & & -0.0005 & & & 349 & 1.1 \\
\hline 4th & & 1.524 & & -0.131 & -0.529 & -0.502 & 0.413 & & -0.0009 & & & 349.1 & 1.2 \\
\hline 5th & & 1.475 & 0.131 & & -0.472 & -0.566 & 0.350 & & -0.0010 & & & 349.2 & 1.3 \\
\hline 6th & & 0.722 & 0.265 & -0.241 & -0.586 & -0.622 & 0.308 & & & 0.037 & & 349.2 & 1.3 \\
\hline 7th & & 1.494 & & & -0.458 & -0.535 & 0.453 & -0.0002 & -0.0009 & & & 349.2 & 1.3 \\
\hline 8th & & 1.439 & & -0.214 & -0.489 & -0.456 & 0.406 & & & & & 349.3 & 1.4 \\
\hline 9th & & 1.499 & 0.203 & -0.215 & -0.542 & -0.572 & 0.365 & -0.0001 & & & & 349.5 & 1.6 \\
\hline 10th & & 1.475 & & -0.176 & -0.487 & -0.499 & 0.473 & -0.0002 & & & & 349.6 & 1.7 \\
\hline
\end{tabular}

139 
151 Table A8. Results of model selections for the genetic diversity of V. pycnostelma based on AIC. Estimated coefficients for selected explanatory variables, AICs 152 and $\triangle$ AICs (the difference between each AIC value and the smallest value) are indicated for the lowest ten models of AICs. Bold numbers indicate that the 95\% 153 confidence interval (CI) for the partial regression coefficient did not include zero.

\begin{tabular}{|c|c|c|c|c|c|c|c|c|c|c|c|c|}
\hline \multirow[b]{2}{*}{ Model } & \multirow[b]{2}{*}{ Intercept } & \multicolumn{5}{|c|}{ Mowing timing } & \multirow[b]{2}{*}{$\begin{array}{l}\text { Area } \\
\left(\mathrm{m}^{2}\right) \\
\end{array}$} & \multirow[b]{2}{*}{$\begin{array}{c}\text { Population } \\
\text { size } \\
\end{array}$} & \multirow[b]{2}{*}{$\begin{array}{c}\text { Mean } \\
\text { temperature }\end{array}$} & \multirow[b]{2}{*}{$\begin{array}{c}\text { Mean } \\
\text { precipitation }\end{array}$} & \multirow[b]{2}{*}{ AIC } & \multirow[b]{2}{*}{$\triangle \mathrm{AIC}$} \\
\hline & & $\begin{array}{c}\text { During Apr. } \\
\text { and May }\end{array}$ & In Jun. & In Jul. & $\begin{array}{c}\text { During } \\
\text { Aug. and } \\
\text { Sep. }\end{array}$ & $\begin{array}{c}\text { During } \\
\text { Nov. to } \\
\text { Mar. }\end{array}$ & & & & & & \\
\hline \multicolumn{13}{|l|}{$H_{\mathrm{E}}$ (arcsin-transformed) } \\
\hline Best model & 0.945 & & & -0.172 & -0.060 & & & -0.0003 & & & -140.1 & - \\
\hline 2nd & 0.886 & & & -0.173 & -0.047 & & & -0.0003 & & 0.00005 & -138.8 & 1.3 \\
\hline 3rd & 0.924 & & -0.049 & -0.170 & -0.037 & & & & & & -138.7 & 1.4 \\
\hline 4th & 1.139 & & & -0.173 & -0.051 & & & -0.0003 & -0.009 & & -138.7 & 1.4 \\
\hline 5th & 0.933 & & & -0.162 & -0.056 & 0.015 & & -0.0003 & & & -138.5 & 1.6 \\
\hline 6th & 0.889 & & -0.060 & -0.139 & & 0.035 & & & & & -138.4 & 1.7 \\
\hline 7th & 0.937 & & & -0.168 & -0.054 & & 0.00002 & -0.0003 & & & -138.4 & 1.7 \\
\hline 8th & 0.944 & 0.016 & & -0.171 & -0.067 & & & -0.0003 & & & -138.4 & 1.7 \\
\hline 9th & 0.944 & & -0.016 & -0.175 & -0.054 & & & -0.0002 & & & -138.3 & 1.8 \\
\hline 10th & 0.927 & 0.041 & -0.057 & -0.174 & -0.056 & & & & & 0.00008 & -138.2 & 1.9 \\
\hline \multicolumn{13}{|l|}{ Allelic richness } \\
\hline Best model & 7.956 & & & -2.438 & -1.010 & & & -0.004 & & & 460.2 & - \\
\hline 2nd & 7.130 & & & -2.447 & -0.839 & & & -0.004 & & 0.0007 & 461.1 & 0.9 \\
\hline 3rd & 7.736 & & & -2.264 & -0.948 & 0.246 & & -0.004 & & & 461.2 & 1.0 \\
\hline 4th & 7.359 & & -0.751 & -2.182 & -0.595 & 0.429 & & & & & 461.2 & 1.0 \\
\hline 5th & 7.802 & & & -2.357 & -0.917 & & 0.0003 & -0.004 & & & 461.4 & 1.2 \\
\hline 6th & 7.705 & 0.567 & -0.810 & -2.471 & -0.959 & & & & & & 461.7 & 1.5 \\
\hline 7th & 7.934 & & -0.258 & -2.486 & -0.919 & & & -0.003 & & & 461.7 & 1.5 \\
\hline 8th & 7.940 & 0.207 & & -2.426 & -1.110 & & & -0.004 & & & 461.8 & 1.6 \\
\hline 9th & 7.661 & & -0.696 & -2.423 & -0.696 & & & & & & 462.0 & 1.8 \\
\hline 10th & 8.581 & & & -2.441 & -0.982 & & & -0.004 & -0.030 & & 462.1 & 1.9 \\
\hline
\end{tabular}


Table A9. Presence of other flowering and fruiting endangered species that coexisted with study Vincetoxicum pycnostelma populations in autumn 2013. Endangered species were defined as species listed as more than near threatened (NT) in at least 5 out of all 47 prefectural Red Lists in Japan (Association of Wildlife Research and Envision Conservation Office, 2007 (http://www.jpnrdb.com/index.html, last accessed 01/10/2013)). 1, presence; 0 , absence, *, selectively conserved by land managers.

\begin{tabular}{|c|c|c|c|c|c|c|c|c|c|c|c|c|c|c|c|c|c|c|}
\hline \multirow{2}{*}{ Family name } & \multirow{2}{*}{ Species name } & \multirow{2}{*}{$\begin{array}{c}\text { Flowerin } \\
\text { g month }\end{array}$} & \multirow{2}{*}{$\begin{array}{l}\text { No. of Prefectural } \\
\text { Red lists } \\
\end{array}$} & \multicolumn{15}{|c|}{ Populations } \\
\hline & & & & $\mathrm{a}$ & $\mathrm{b}$ & C & $\mathrm{d}$ & e & $\mathrm{f}$ & $g$ & $\mathrm{~h}$ & $\mathrm{i}$ & $\mathrm{j}$ & $\mathrm{k}$ & 1 & $\mathrm{~m}$ & $\mathrm{n}$ & $\mathrm{O}$ \\
\hline \multirow[t]{2}{*}{ Apiaceae } & Sium ninsi & $8 \sim 10$ & 24 & 0 & 0 & 0 & 0 & 0 & 1 & 0 & 0 & 0 & 0 & 0 & 0 & 0 & 0 & 0 \\
\hline & Atractylodes ovata & $9 \sim 10$ & 21 & 1 & 0 & 0 & 0 & 0 & 0 & 0 & 0 & 0 & 0 & 0 & 0 & 0 & 0 & 0 \\
\hline & Serratula coronata subsp. insularis & $8 \sim 10$ & 10 & 0 & 0 & 1 & 0 & 0 & 0 & 0 & 0 & 0 & 0 & 0 & 0 & 0 & 0 & 0 \\
\hline Campanulaceae & Platycodon grandiflorus & $8 \sim 9$ & 44 & 0 & 0 & 0 & $1^{*}$ & 0 & 0 & 1 & 0 & 0 & 0 & 0 & 0 & 0 & 0 & 0 \\
\hline \multirow{2}{*}{ Fabaceae } & Dunbaria villosa & $8 \sim 9$ & 9 & 0 & 1 & 0 & 0 & 0 & 0 & 0 & 0 & 0 & 0 & 0 & 0 & 0 & 0 & 0 \\
\hline & Lespedeza virgata & $8 \sim 9$ & 18 & 1 & 0 & 0 & 0 & 0 & 0 & 0 & 0 & 0 & 0 & 0 & 0 & 0 & 0 & 0 \\
\hline \multirow{2}{*}{ Gentianaceae } & Gentiana scabra var. buergeri & 9 11 & 9 & 0 & 0 & 0 & $1^{*}$ & 0 & 1 & 0 & 0 & 0 & 0 & 0 & 0 & 0 & 1 & 0 \\
\hline & Swertia japonica & $10 \sim 11$ & 13 & 0 & 0 & 0 & 1 & 0 & 0 & 0 & 0 & 1 & 0 & 0 & 0 & 0 & 0 & 0 \\
\hline \multirow[t]{2}{*}{ Iridaceae } & Iris ensata var. spontanea & $6 \sim 7$ & 26 & 0 & 0 & 0 & 0 & 0 & 1 & 0 & 0 & 0 & 0 & 0 & 0 & 0 & 0 & 0 \\
\hline & Allium thunbergii & $9 \sim 10$ & 9 & 0 & 0 & 0 & 0 & 0 & 1 & 1 & 1 & 0 & 0 & 0 & 0 & 0 & 0 & 0 \\
\hline Saxifragaceae & Parnassia palustris var. palustris & $8 \sim 10$ & 20 & 0 & 0 & 0 & 0 & 0 & 0 & 0 & 0 & 0 & 0 & 0 & 0 & 0 & 1 & 0 \\
\hline Scrophulariaceae & Siphonostegia laeta & 8 & 20 & 1 & 0 & 0 & 0 & 0 & 0 & 0 & 0 & 0 & 0 & 0 & 0 & 0 & 0 & 0 \\
\hline \multirow[t]{2}{*}{ Valerianaceae } & Patrinia scabiosifolia & $8 \sim 10$ & 18 & 1 & 0 & 0 & 0 & 0 & 0 & 1 & 0 & 1 & 0 & 0 & 0 & 0 & 0 & 0 \\
\hline & Total species number & & & 4 & 2 & 1 & 1 & $\mathbf{0}$ & 5 & 7 & 1 & 2 & $\mathbf{0}$ & $\mathbf{0}$ & 1 & $\mathbf{0}$ & 2 & $\mathbf{0}$ \\
\hline
\end{tabular}


Table A10. Estimated coefficients of explanatory variables in the best generalized linear model with Poisson errors and loglink function for endangered species found near V. pycnostelma in the study sites. Bold numbers indicate that the $95 \%$ confidence interval (CI) for the partial regression coefficient did not include zero. AIC, Akaike's information criterion.

\begin{tabular}{|c|c|c|c|c|c|}
\hline \multirow{2}{*}{ Explanatory variable } & \multirow{2}{*}{ Coefficient } & \multicolumn{2}{|c|}{ 95\% Confidence interval } & \multicolumn{2}{|c|}{ AIC } \\
\hline & & Lower limit & Upper limit & Null model & Best model \\
\hline Mowing in Jun. & 0.676 & -0.156 & 1.508 & 62.5 & 54.5 \\
\hline Mowing during Aug. and Sep. & -1.170 & -2.396 & 0.056 & & \\
\hline Area $\left(\mathrm{m}^{2}\right)$ & -0.001 & -0.003 & -0.000 & & \\
\hline Mean temperature & -0.460 & -0.956 & 0.036 & & \\
\hline Intercept & 10.756 & 0.239 & 21.274 & & \\
\hline
\end{tabular}


179 180

Figure A1. Location map of studied Vincetoxicum pycnostelma populations in the Kinki and Tokai districts (a). Location of the Kinki and Tokai districts in Japan (b).

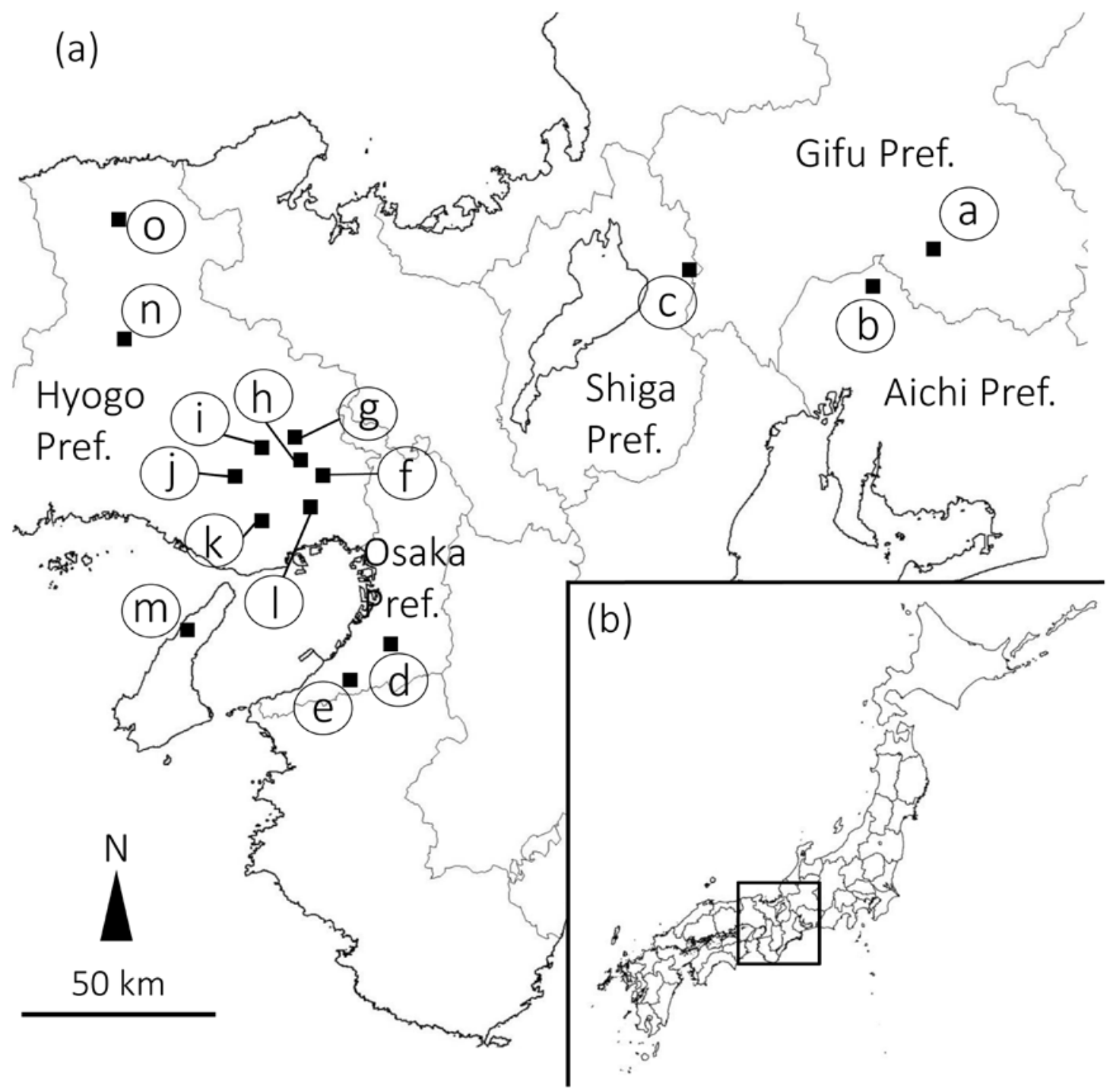


195

196

197

198

Figure A2. The relationships between genetic $\left(D_{\mathrm{A}}\right)$ and geographic distances (logarithmic transformed kilometers) between two sites. There were no significant correlation $\left(P=0.057, r^{2}=0.093\right)$.

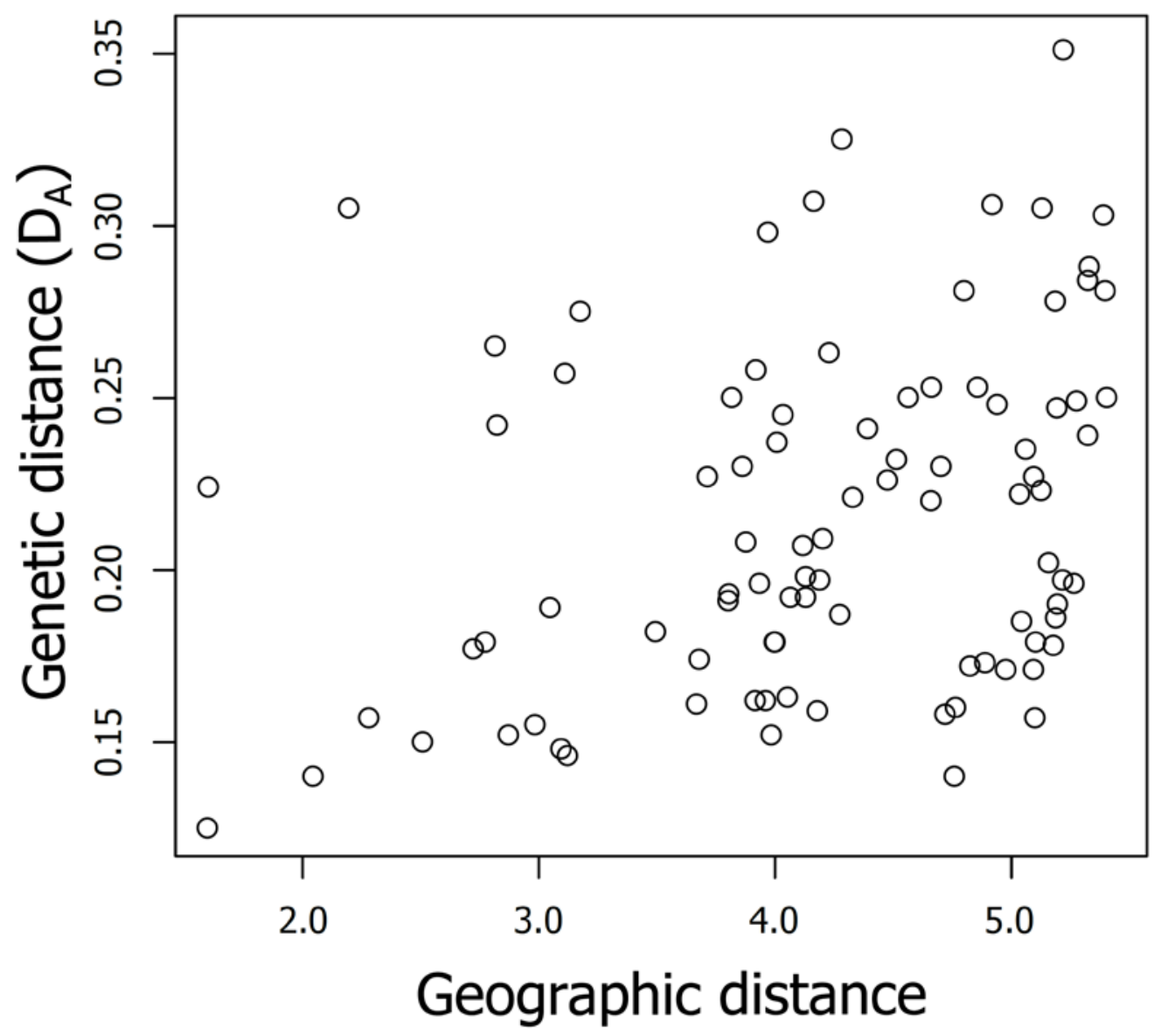


215 Figure A3. Genetic structure using STRUCTURE analysis (Pritchard et al., 2000).

(a)

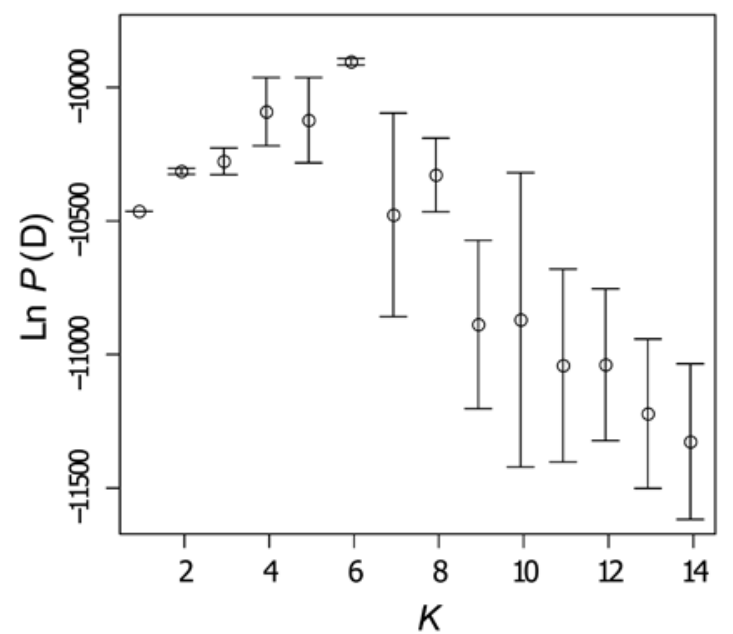

(b)

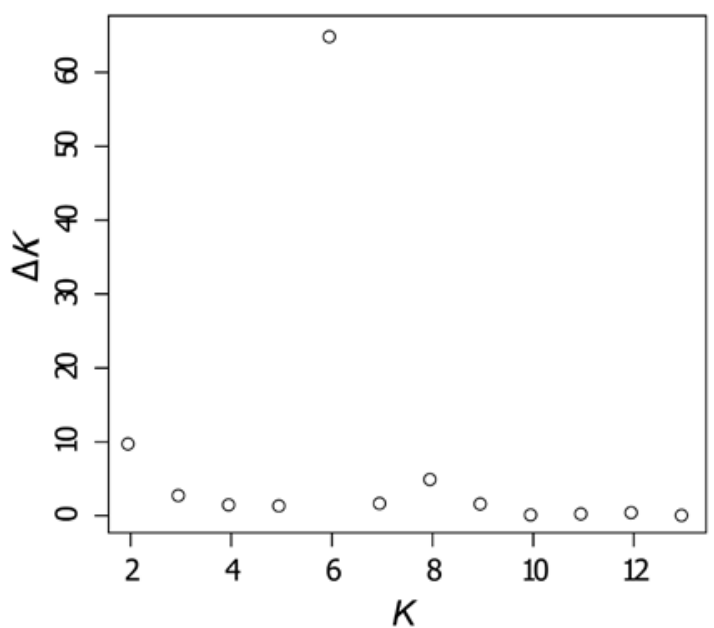

(c)

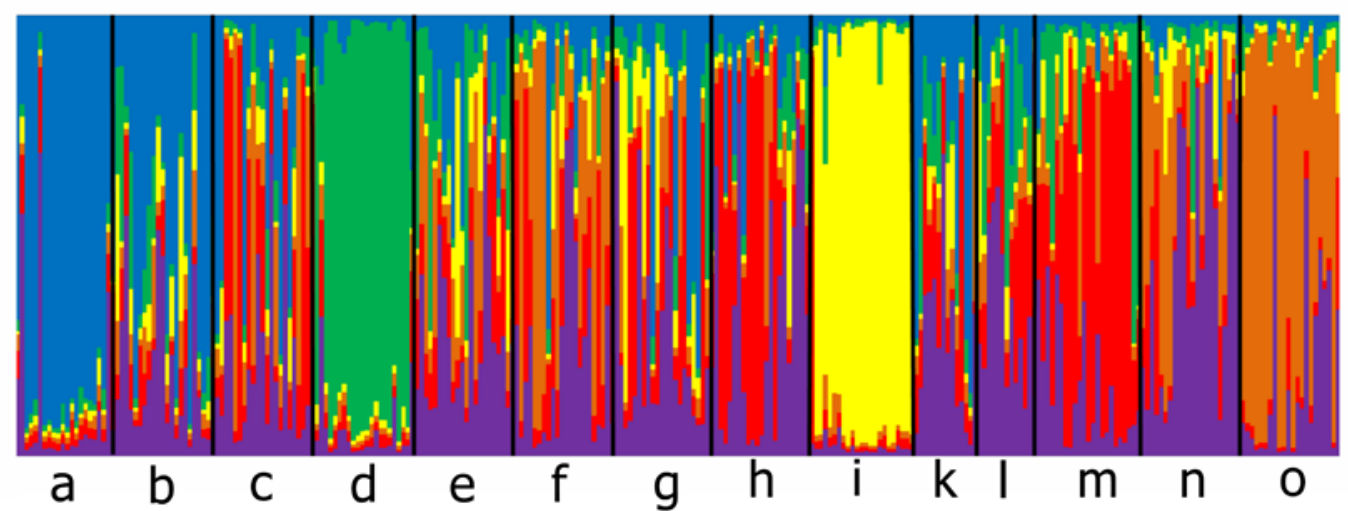

EAST

WEST

(a) Value of the estimated ln probability of data $(\ln P(D))$ for $K=1-14$ (means \pm SD).

(b) $\Delta K$ based on the rate of change in the log probability of data between successive $K$

219 values (Evanno et al., 2005). (c) The proportion of the membership coefficient of 292 in 22014 populations for each of the inferred clusters for $K=6$. Each column represents an individual. 
225 Reference

226 Evanno, G., Regnaut, S., Goudet, J., 2005. Detecting the number of clusters of

227 individuals using the software Structure: a simulation study. Mol. Ecol. 14,

$228 \quad 2611-2620$.

229 